University of Rhode Island

DigitalCommons@URI

Open Access Dissertations

1971

\title{
LIVER ENLARGEMENT AND THE MODIFICATION OF HEPATIC MICROSOMAL DRUG METABOLISM BY PYRETHRUM
}

Angela Caretta Springfield

University of Rhode Island

Follow this and additional works at: https://digitalcommons.uri.edu/oa_diss

\section{Recommended Citation}

Springfield, Angela Caretta, "LIVER ENLARGEMENT AND THE MODIFICATION OF HEPATIC MICROSOMAL DRUG METABOLISM BY PYRETHRUM" (1971). Open Access Dissertations. Paper 166.

https://digitalcommons.uri.edu/oa_diss/166

This Dissertation is brought to you for free and open access by DigitalCommons@URI. It has been accepted for inclusion in Open Access Dissertations by an authorized administrator of DigitalCommons@URI. For more information, please contact digitalcommons-group@uri.edu. 
LIVER ENLARGEMENT AND THE MODIFICATION OF HEPATIC MICROSOMAL DRUG METABOLISH BY PYRETHRUM

BY

ANGELA CARETTA SPRINGFIELD

\begin{abstract}
A THESIS SUBMITTED IN PARTIAL FULFILLMENT
OF THE REQUIREMENTS FOR THE DEGREE OF

DOCTOR OF PHILOSOPHY
\end{abstract}

IN

PHARMACEUTICAL SCIENCES

UNIVERSITY OF RHODE ISLAND

1971 


\section{DOCTOR OF PHILDSOPHY THESIS \\ DF}

ANGELA CARETTA SPRINGF IELD

Approved:

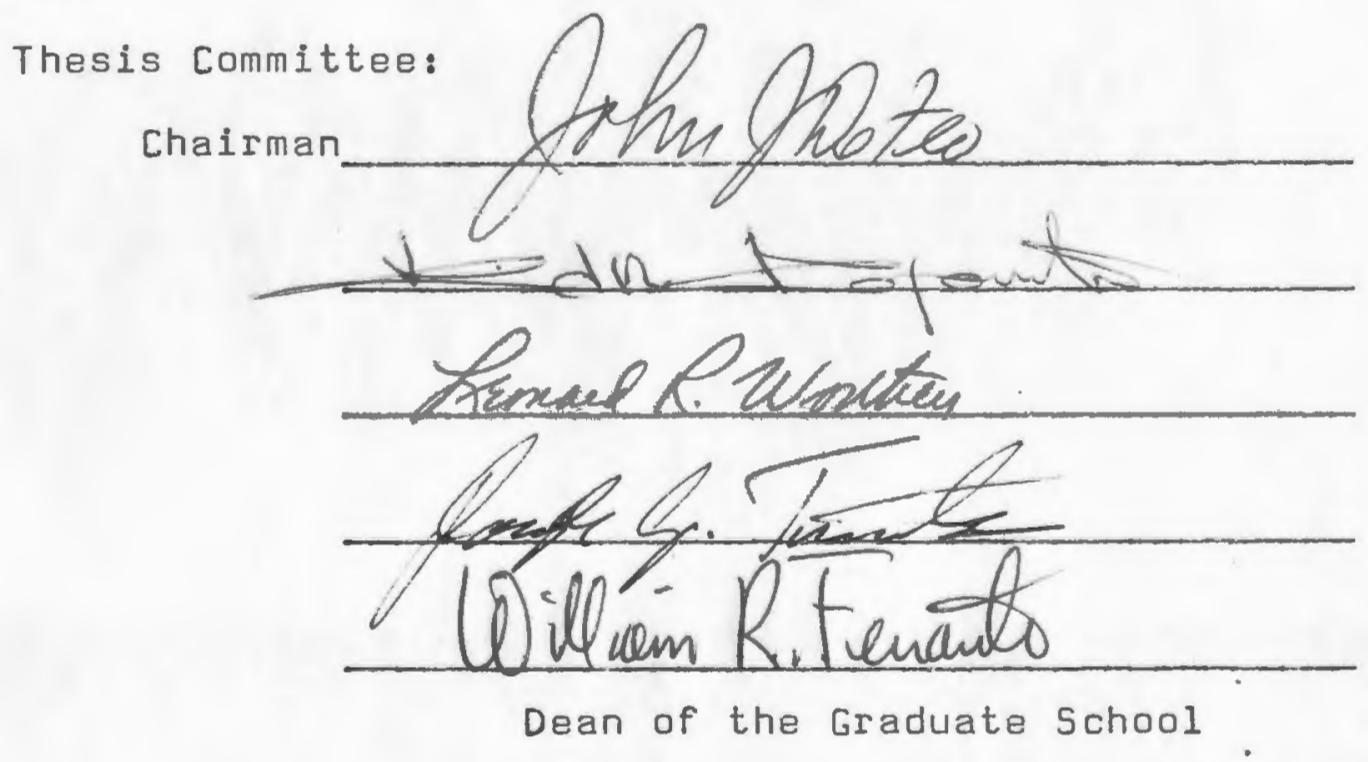

UNIVERSITY OF RHODE ISLAND 


\section{ABSTRAC.T}

Liver enlargement in rats resulting from oral administration of pyrethrum has been observed in various laboratories. This study was undertaken to investigate the nature of this enlargement as well as resulting changes in hepatic drug metabolism. Oral administration of pyrethrum at $200 \mathrm{mg} / \mathrm{kg}$ for 13 or 23 days resulted in decreases in hepatic DNA concentrations. While total lipid concentrations were increased significantly, the increases did not account for the enlargement. Protein concentrations of whole liver homegenates, 9,000 $\times 9$ supernatants and the $105,000 \times 9$ pellet were not different from controls. No significant changes occurred in hepatic water concentrations. Accompanying histological observations of the enlarged livers indicated cellular hypertrophy。

Significant decreases in hexobarbital induced hyprosis without conconitant changes in barbital induced hypnesis suggested a pyrethrum caused alteration in hepatic drug metabolism. The activities of hepatic microsomal enzymes responsitile for EPN detoxification, p-nitroanisoie deriethylation and hexo-barbital oxidation were increased to 150,173 and 241 percent of control, respectively. No significant jncreases were noted in the demethylation of aminopyrine or oxidation of L-tryptophan. Increases in liver weight, the detoxioication of EPN and demethylation of ponitrodrisole wez found bo se cuse relatec. 
Increased enzyme activities were abserved at the lowest dose used of $85 \mathrm{mg} / \mathrm{kg} / \mathrm{day}$ for 15 days. At a dose of $500 \mathrm{mg} / \mathrm{kg} /$ day, liver wgights and enzyme activities were increased continually during a 17 day period of treatment but returned to control level within 7 days after cessation of treatment. NADPHcytochrome c reductase and P-450 concentrations were also increased. These data show that pyrethrum causes significant liver enlargement with accompanying increases in microsamal drug metabolizing activity. They suggest a re-evaluation of the use of pyrethrum as a non-inducing insecticide. 


\section{ACKNDWLEDGEMENTS}

The author wishas to express her gratitude to her parents Mr. and Mrs. James Branyon Springfield for their support, understanding and inspiration.

The guidance provided by Dr. John J. Defeo and Dr. Gary P. Carlson during the course of these studies is greatly appreciated. The author wishes to thank her friends for the many helpful suggestions offered throughout this investigation. This work was supported in part by a National Defense Education Act pre-doctoral fellowship. 
TABLE OF CONTENTS

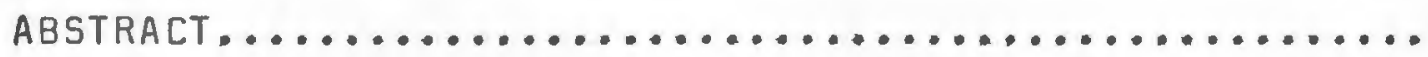

ACKNOWLEDGEMENTS............................ i ii

TABLE OF CONTENTS............................ 1

LIST OF TABLES............................... 3

LIST OF FIGURES.............................. 5

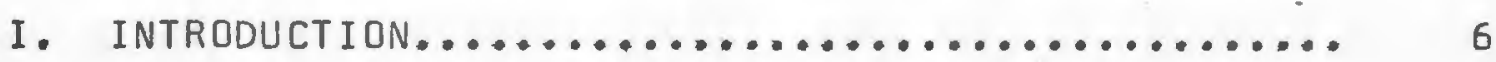

II. REVIEW OF THE LITERATURE.....................

A. Pharmacology of the Pyrethrins.............. g

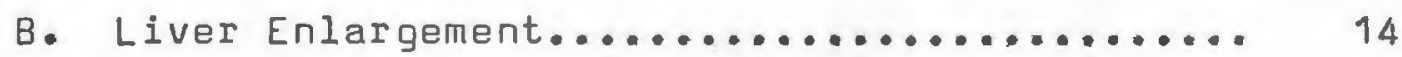

III. EXPERIMENTAL ......................... 17

A. Animals................................ 17

B. Materials............................ 17

C. Measurement of Drug Induced Narcosis........ 17

D. Preparation of Rat Liver Supernatant

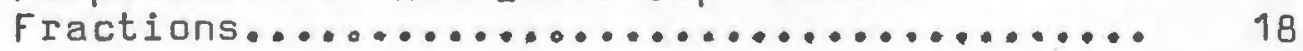

E. Analytical Procedures...................... 18

1. Determination of Hepatic Water Concentrations.........................

2. Determination of Hepatic Total Lipids.... 19

3. Determination of Hepatic DNA........... 20

4. Determination of Hexobarbital Oxidation.. 21

5. Determination of Hexobarbital Serum Levels...........................

6. Determination of Aminopyrine N-Demethyl-

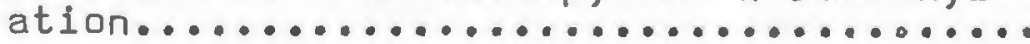


7. Determination of $\mathrm{P}-\mathrm{Chloro-N-methyl-}$

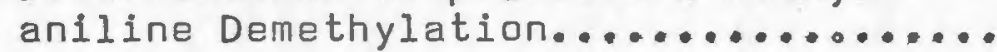

8. Determination of EPN Detoxification and p-Nitroanisole Demethylation..........

9. Estimation of Protein................

10. Determination of L-Tryptophan Pyrrolase

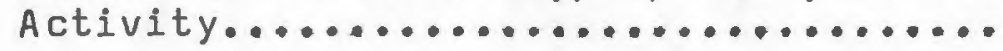

11. Determination of NADPH-Cytochrome c

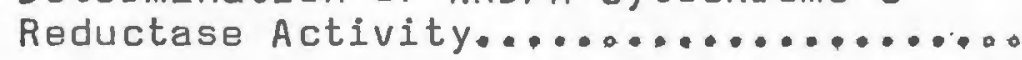

12. Determination of CO-Binding Pigment

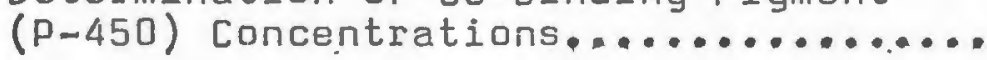

F. Statistical methods.................... 28

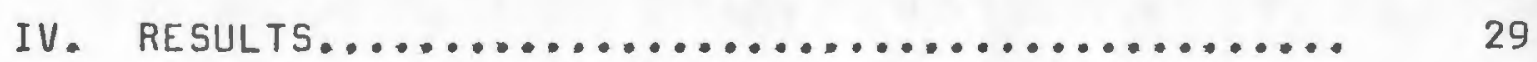

V. DISCUSSIDN............................... 55

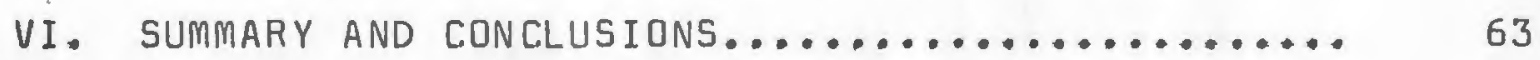

VII. REFERENCES.......................... $6 . \ldots$ 


\section{LIST OF TABLES}

Table

Page

1. Effect of pyrethrum, $200 \mathrm{mg} / \mathrm{kg} /$ day orally for 23 days, on liver weight, total lipids and water content...........................

2. Effect of pyrethrum, $200 \mathrm{mg} / \mathrm{kg} /$ day orally for 13 days, on liver weight, protein and DNA.....

3. Effect of pyrethrum, $200 \mathrm{mg} / \mathrm{kg} /$ day orally for 6 days, on hexobarbital and barbital induced narcosis..............................

4. Effect of pyrethrum, $200 \mathrm{mg} / \mathrm{kg} /$ day orally for 12 days, on hexobarbital induced narcosis and hexobarbital serum levels at return of

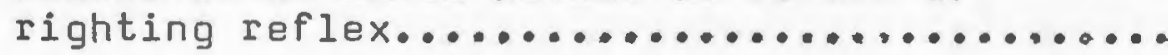

5. Effect of pyrethrum, $200 \mathrm{mg} / \mathrm{kg} /$ day orally for 23 days on aminopyrine damethylation and hexobarbital oxidation by $9,000 \times$ g supernatants..

6. Effect of pyrethrum, $200 \mathrm{mg} / \mathrm{kg} /$ day orally for 12 days, on $\mathrm{p}$-chloro-N-methylaniline demethylation and aminopyrine demethylation by 9,000

x g supernatants.......................

7. Effect of pyrethrum, $200 \mathrm{mg} / \mathrm{kg} /$ day orally for 13 days, on EPN detoxification, p-nitroanisole demethylation and hexobarbital oxidation by 9,000 x g supernatants.....................

8. Effect of pyrethrum, three dose levels orally for 15 days, on body weight and liver to body welght ratio..........................

9. Effect of pyrethrum, three dose levels orally for 15 days, on liver protein concentrations..

10. Effect of pyrethrum, three dose levels orally for 15 days, on the detoxification of EPN and demethylation of p-nitroanisole by $9,000 \times 9$ supernatants.........................

11. Effect of pyrethrum, $500 \mathrm{mg} / \mathrm{kg} /$ day orally, on liver welght to body weight ratios............ 
Table

12. Effect of pyrethrum, $500 \mathrm{mg} / \mathrm{kg} / \mathrm{day}$ orally, on the detaxification of EPN by $9,000 \times 9$ super-

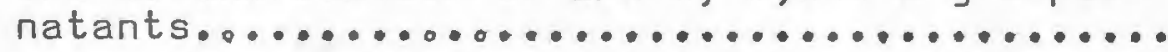

13. Effect of pyrethrum, $500 \mathrm{mg} / \mathrm{kg} /$ day orally, on the demethylation of p-nitroanisole by 9,000 x g supernatants.......................

14. Effect of pyrethrum, $500 \mathrm{mg} / \mathrm{kg} /$ day orally, on the oxidation of L-tryptophan by $9,000 \times 9$ supernatants........................

15. Effect of Pyrethrum, $500 \mathrm{mg} / \mathrm{kg} /$ day orally, on NADPH-cytochrome c reductase activity of

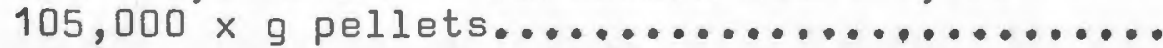

16. Effect of pyrethrum, $500 \mathrm{mg} / \mathrm{kg} /$ day orally for 4 days, on components of the NADPH-linked electron transport system in liver microsomes and EPN detoxification and p-nitroanisole demethyl-

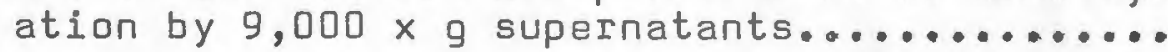




\section{LIST OF FIGURES}

Figure

1. Effect of pyrethrum, $200 \mathrm{mg} / \mathrm{kg} /$ day orally for 23 days, on aminopyrine demethylation by 9,000 $x$ g supernatants......................

2. Composite graph: Effect of pyrethrum, three dose levels orally for 15 days, on the liver to body weight ratio, detoxification of EPN

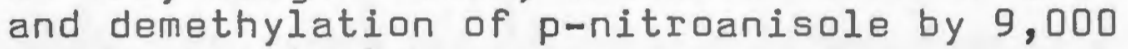
$x$ supernatants........................

3. Composite graph: Effect of pyrethrum, 500 $\mathrm{mg} / \mathrm{kg} /$ day orally, on the liver to body weight ratio, detoxification of EPN and demethylation of p-nitroanisole by $9,000 \times 9$ supernatants and NADPH-cytochrome c reductase activity in microsomes........................... 


\section{INTRODUCTION}

In recent years increasing interest has developed in the toxicity of the various classes of pesticides. The organochlorine insecticides, and DDT in particular, are of growirlg ecological concern becauss of their widespread use and extreme persistence and the difficulty in evaluating the harmful effects of these low residues upon such parameters as the fertility of animals and fragility of bird eggs (O'Brien, 1967). The unrestricted use of these halogenated hydrocarbons in laboratory animal quarters has also been of concern (Fouts, 1963). Since enzyme induction can seriously affect the results of tests meant to evaluate the metabolism or the acute or chronic toxicity of drugs, care should be taken to exclude such insecticides from quarters of animals used in such studies (Conney, 1967). Another type. of insacticide, the organophosphates, for example parathion and malathion, are inhibitors of cholinesterase. Although they are rapidly hydrolyzed and thus are not persistent, the acute mammalian toxicity is high.

Pyrethrum, an extract of the pyrethrum flower Chrysanthemum cinarariaefolium, contains four esters of complex alcohols and acids called pyrethrin I and II and cinerin I and II (Shepard, 1939). As an insecticide, it has found wide use in agriculture, forestry, the home, and laboratory animal quarters because of its favorable properties. It demonstrates a low mammalian 
toxicity (Negherbon, 1959), but at the same time has a high knockdown and kill rate on many classes of insects (Metcalf, 1955). Instability towards mild acid or alkali, and direct sunlight limits its persistence in the environment (Chen and Casida, 1969). It has been generally assumed that pyrethrum is safe for use in situations requiring a non-inducing insecticide, such as in quarters housing animals undergoing pharmacological testing (Fouts, 1963; Conney, 1967). Although no data was presented, the use of pyrethrum and piperonyl butoxide was recommended since there was no detected effect of these materials on hexobarbital induced narcosis or microsomal drug metabolizing enzyme activity.

In examining the combined effects of DDT, pyrethrum, and piperonyl butoxide, Kimbrough et al (1968) found that pyrethrum, especially synergized pyrethrum, produced liver enlargement and cellular changes including margination and cytoplasmic inclusions. These changes were proportional to dosage and similar in character to changes caused by DDT. However, these studies were concerned only with morphological changes and did not include biochemical observations. Results from our laboratory of 90 day toxicity studies conducted in rats employing 25 percent of the oral $L D 50$ also showed that pyrethrum, piperonyl butoxide, tropital and sulfoxide, alone and in combination, caused liver enlargement (Bond and Defeo, 1967-1968).

Liver enlargement which may be indicative of abnormal structural changes or other pathology often accompanies the 
stimulation or inhibition of drug biotransformation (conney, 1967). Since the rate of hepatic drug biotransformation influences the resultant pharmacodynamic activity of a compound (Conney, 1967), it seemed important to examine the nature of the liver enlargement caused by pyrethrum, as well as possible alterations in the hepatic biotransformation of drugs.

Initial investigations were designed to explone the physical causes of the enlargement, i.e., whether due to edema, fat deposition, hyperplasia, or hypertrophy. Further studies examined the nature and extent of alterations in hepatic biotransformation of drugs while additional work suggested a possible mechanism for such alterations. 


\section{REVIEW OF THE LITERATURE}

A. Pharmacology of the Pyrethrins.

Early work dealing with the toxicity of pyrethrum centered on its effects on mammals. The reported results varied with route of administration, species and vehicle used (Shimkin and Anderson, 1936; Ambrose and Robbins, 1951; Negherbon, 1959; Bond and Defeo, 1967-1969). The acute oral LD50 in rats for an 86.2 percent solution of pyrethrins was greater than 2.6 $\mathrm{g} / \mathrm{kg}$. No mortality was observed in rats administered $1.6 \mathrm{~g} / \mathrm{kg}$ subcutaneously (Ambrose and Robbins, 1951). Negherbon (1959) reported an oral LD50 for rats of $820 \mathrm{mg} / \mathrm{kg}$ and $1500 \mathrm{mg} / \mathrm{kg}$ for guinea pigs. A dose of $6-8 \mathrm{mg} / \mathrm{kg}$ was toxic to dogs when administered intravenously, suggesting that pyrethrum possessed a potent intrinsic toxicity. The acute oral LD50 in rats for a commercial solution of pyrethrum ( 20 percent pyrethrins, 80 percent petroleum distillates) was $7200 \mathrm{mg} / \mathrm{kg}$ or the equivalent of $1440 \mathrm{mg} / \mathrm{kg}$ of pyrethrum alone (Bond and Defeo, 1967-1969). The acute oral LD50 in rats for pyrethrin I dissolved in dimethylsulfoxide was reported to be $260-420 \mathrm{mg} / \mathrm{kg}$ while that of pyrethrin II was greater than $600 \mathrm{mg} / \mathrm{kg}$.

Administered orally in 6 doses over 12-54 hour periods, rats survived $450-2000 \mathrm{mg} / \mathrm{kg}$ of pyrethrin I and greater than $2900 \mathrm{mg} / \mathrm{kg}$ of pyrethrin II (Cassida et al, 1971). Carpenter et al. (1950) found that rats were able to ingest over a 24 hour 
period a quantity which was lethal if administered in a single dose and were able to maintain the intake for long periods without apparent injury. Bond and Defeo (1967-1969) noted that rats were able to tolerate a dose of $\frac{1}{4}$ the oral LD50 for periods of 90 days without significant increases in mortality over that of controls.

The chronic dermal toxicity of pyrethrum (20 percent pyrethrum, 80 percent petroleum distillates) to rabbits and the chronic vapor toxicity to mice, rats, guinea pigs and rabbits, as well as the associated histopathology of these animals is reported by the office of the Surgeon General (1951, 1952). Slight to mild skin irritation was observed in rabbits upon application of $1 \mathrm{ml} / \mathrm{kg} /$ day for approximately 30 days, with further applications progressing in severity. However, these same effects were produced by the solvent which was tested alone, suggesting that the effects were not dus to pyrethrum but to the solvent. Continuation of exposure to saturated vapors of pyrethrum extract for 5 weeks, 8 hours daily, 5 days per week caused a 40 percent mortality in mice; preening, eye irritation and unthrifty appearance in rats; unthrifty appearance in guinea pigs; and no apparent effects in rabbits. On a comparable basis, vapors from the solvent appeared to be more toxic than the extract and accounted for the toxicity of extract. The histopathology of the tissues from these animals showed primarily vascular congestion which was more pronounced in the lungs and kidneys than other tissues. These effects 
were more severe in solvent treated animals. Early studies by Feinberg (1934), Garratt and Bigger(1923), and mecordet al (1921) showed that skin contact and inhalation may cause allergenic attacks in sensitive people. Patients sensitive to ragueed developed allergic reactions to extracts of ground pyrethrun flowers; severe dermatitis and anaphylactoid reactions Nere also reported. More recent studies using refined pyrethrum suggested that there was no potential allergy to insecticides containing pyrethrins, as opposed to the unrefined material (Zucker, 1965).

Structurally related new synthetic derivatives of pyrethrum demonstrated toxicities similar to that of pyrethrum: allethrin (Ambrose and Robbins, 1951; Carpenter et al, 1950); Starr et al, 1950a, 1950b), barthrin (Ambrosa, 1963; Masri et a.1, 1964a, 1964b), dimethrin (Ambrose, 1964; Masri et al , 1964a, 1964b) and others (Chikamoto, 1964). Increased liver and kidney weights were noted in animals chronically fed barthrin or dimethrin (Ambruse, 1963, 1964) together with the reversible appearance of hepatic cytoplasmic inclusions (Masri et al, 1964b).

many revieuers of this subject conclude that the effective and rapid knockdown action of pyrethrum in insects results from an initial impairment of neuromotor systems (Shepard, 1951; Roeder, 1953; Metcalf, 1955; Negherbon, 1959; 0'Brien, 1967). Earlier studies with arthropod nerves showed that direct application of pyrethrum caused initial excitation followed by block (Ellis et al, 1942; Lcyenstein, 1942; welch and Gordon, 1947). Allethrin and other synthetics act in a 
similar manner causing repetitive discharge, negative after potential and conduction block and have been tested in cockroach giant axon fibers (Narahashi, 1962a, 1962b), squid giant axons (Narahashi and Anderson, 1967) and crayfish giant axons (Berteau et al, 1968; Camougis et al, 1971) with microelectrode techniques. Pyrethrum in low concentrations will block crustacean synapses (Schallek and Wiersma, 1948). However, the exact part of the system involved, central versus peripheral, is a matter of controversy (Kearns, 1956). Pyrethrum does act on the sensory nerve, endings causing temporary paralysis, and further poisoning effects may occur from localized action along the axon. Centrally, pyrethrum stimulates repetitive discharge of nerve cells and fibers and later results in paralysis.

In contrast to the relatively numerous studies with arthropods, little information exists on the direct action of pyrethrum on vertebrate nerve. The gross syndrome in mammals includes excitation, tremor and convulsion suggesting actions on the nervous system (Negherbon, 1959; Hayes, 1965). Camougis et al (1971) made a comparative study of the neuropharmacoloical basis of action of pyrethrins in arthropods and vertebrates. The results from isolated nreve preparations showed that spontaneously active ganglia, or the electrically stimulated peripheral nerve of the crayfish, was particularly sensitive to the blocking effects of pyrethrum, but insensitive to lidocaine. In contrast, both the frog nerve and rat nerve were resistant to acute block by pyrethrum but sensitive to lidocaine. 
These apparent differences could not be attributed to the vertebrate nerve sheath, as shown in desheathed nerve preparations, and suggested a possible basic difference in the mechanisms of action. In whole animal studies, low doses of pyrethrum, 1-10 ug/kg, disrupted and blocked electrical activity of the heart in crayfish while doses as high as. $1000 \mathrm{mg} / \mathrm{kg}$ failed to stop the frog heart.

The earliest work on the metabolism of pyrethrum in insects led to the suggestion and virtual assumption that hydrolysis of the ester.group was a major metabolic route (Bridges, 1957; Chamberlain, 1950; Chang and Kearns, 1964; O'Brien, 1967; Winteringham et al, 1955; and Zeid et al, 1953). These studies had limited success because the radiolabeled compounds used had either low specific activity, were mixtures of isomers or were otherwise impure.

Several $C^{14}$-labeled pyrethroids, stereochemically pure isomers of high activity, were recently synthesized (Nishizwa and Casida, 1965; Yamamoto and Casida, 1968). With these compounds it was possible to show that allethrin, pyrethrin I, phthalthrin and dimethrin vere metabolized in living houseflies and in vitro, in the housefly mixed-function oxidase system. Attack occurred at the trans-(major site) and cis(minor site) methyl groups of the isobutenyl side chain in the acid, forming in sucession, the corresponding hydroxymethyl, aldehyde, and acid compounds. No hydrolysis or attack on the alcoholic part of the ester was detected (Yamamoto and Casida, 1966; Yamamoto st al, 1969)。 
While there is some information about the metabolism of pyrethrin I and related compounds in houseflies, relatively little is known about its fate in mammals. The most recent work (Casida et al, 1971) indicated that in rats each of the principal metabolites of pyrethrin I and II retained the cyclopropane ester linkage and was formed by modification of both the acid and the alcohol moieties. The sites of attack were the trans-methyl group on the side chain of the acid and the double bond of the alcohol side chain. However, with allethrin, there was also hydroxylation at the methylene group of the allyl side chain and hydrolysis of the central ester linkage. When barthrin and dimethrin was fed to rabbits, chrysanthemumic acid and the correspcinding alcohols or acids were recovered from the urine (Masri et al, 1964), though the major part of the metabolite was not identified.

B. Liver Enlargement

The physiological significance of enhanced liver growth and function in animals treated with various drugs has not yet been determined and it is not clear whether these effects are harmful or beneficial (Conney, 1967). While enlargement of the liver is generally regarded as a pathological phenomenon (Kunz, 1966), the concern lies, with the increase in relative liver weight in the absence of histopatholoical effects indicative of liver damage (Golberg, 1964).

Organ weight is related to body weight according to the principle of allowetry, so that a log-log plot of body weight against liver weight yields a straight line (Addis and Gray, 
1950). Published data for the rat varies somewhat in this respect (Zumoff and Pachter, 1964; Setnikar and Magistretti, 1965), and attention has been called to the error introduced by comparisons of organ weights of rats when the body weights are consistently different (Setnikar and Magistretti, 1965). However, data for some strains of rats in common use revealed satisfactory liver to body weight correlations at 13 and 25 months (Sherman, 1963).

Phenobarbital increased drug-metabolizing activity in hepatic microsomes and exerted an anabolic effect on the liver which resulted in a 20-40 percent increase in micrasomal protein per g liver. (Conney et al, 1960; Conney and Gilman, 1963). In contrast, 3-methylcholanthrene, a polycyclic hydrocarbon, stimulated liver growth and the synthesis of total liver protein with little or no increase in the concentration of microsomal protein (Conney and Gilman, 1963; Arcos et al, 1961). These studies suggested that the ability of polycyclic hydrocarbons to stimulate liver growth was related to their ability to induce microsomal enzyme formation (Arcos et al, 1961). Some drugs, such as chloroform, halothane and penthrane, caused liver enlargement without enhanced liver microsomal activity and the enlargement was showr biochemically not to be due to fat or edema (Kunz, 1964; Kunz et al, 1966). In a structure activity relationship study of phenol derivatives, no correlation was found between the enhancement of liver growth and stimulation of aminopyrine demethylation or hexobarbital oxidation (Golberg, 1964; Gilbert et al, 1969). 
In view of the diversified effects of various drugs on the liver, it was of interest to determine what biochemical effects would be associated with liver enlargement due to pyrethrum. 


\section{EXPERIMENTAL}

A. Animals

Sprague-Dawley random bred, male albino rats obtained from Charles River Breeding Laboratories, Wilmington, Mass., weighing 100-300 g were used. The animals were housed in quarters maintained at $21-23^{\circ} \mathrm{C}$ with room lights on alternating 12 hour light-dark cycles. Commercial laboratory chow and water were allowed ad libitum. Animals were used no earlier than 5 days following receipt from the supplier. Pyrethrum and corn oll were administered by oral intubation, while all other drugs were administered intraperitoneally.

B. Materials

Analytical grade chemicals or equivalent were used throughout this study. Cofactors (NADP, NADPH and glucose-6-phosphate) and substrates (cytochrome c, L-tryptophan and p-chloromethylaniline were obtalned from Calbiochem., Los Angles, Calif. or from Sigma Chemicals, St. Louis, Mo. Crystalline bovine serum albumin was ottained from Armour Laboratories, Kankakee, IIl.. Drugs used were obtained from their respective manufacturers. Pyrethrum, 20 percent mixture of pyrethrins I and II and cinerin I and II in corn oil, was obtained from the McLaughlin Gormley King Co., Inc., Minneapolis, Minn.. Mazola corn oil was used as the control vehicle.

c. Measurement of Drug-Induced Narcosis

Duration of hexobarbital induced narcosis was taken as 
the interval between injection of the drug and the return of righting reflex, the endpoint of which was determined according . to Wenzel and Lal (1959) using two rightingswithin 30 sec. Barbital induced narcosis was measured as the time of loss and the return of righting reflex. The interval between injection of the drug and loss of righting reflex was designated as onset of narcosis.

D. Preparation of Rat Liver Supernatant Eractions Rats wers guillotined 24 hours subsequent to the last administered dose of pyrethrum or corn oil. Livers were perfused in situ with ice-cold $0.15 \mathrm{~m} \mathrm{KCl}$ and were homogenized in 2-3 volumes of ice-cold $0.1 \mathrm{~m}$ phosphate buffer $(\mathrm{pH} 7.4)$ at 1000 RPM for 1 min in a coaxial glass homogenizer with teflon pestle. The 9,000 $\times 9$ supernatant fraction uas obtained by centrifugation at $0^{\circ} \mathrm{C}$ for $30 \mathrm{~min}(10,000 \mathrm{rpm}$ in a Model B-60 International Preparative Ultracentifuge (IEC) \#874 rotor). Portions of this fraction were then stored at $-20^{\circ} \mathrm{C}$ until assayed.

The $105,000 \times 9$ pellet was obtained by centrifuging aliquots of the $9,000 \times g$ supernatant at $0^{\circ} \mathrm{C}$ for 2 hours in an IEC preparative ultracentrifuge, \#A-170 rotor, 37,000 rpm. This pellet was dispersed in $0.1 \mathrm{~m}$ phosphate buffer ( $\mathrm{pH} 7.4$ ) and stored at $-20^{\circ} \mathrm{C}$ until assayed. In instances when only the protein concentration of this pellet was determined, the pellet was digested in $0.5 \mathrm{~m} \mathrm{NaOH}$ and assayed. E. Analytical Procedures

All incubations were carrled out in a Dubnoff metabolic shaker under air. All absorbance readings were determined in 
a Beckman DB-G spectrophctometer.

1. Determination of Hepatic Water Concentrations

Four mi aliquots of whole liver homogenate equal to $1.0 \mathrm{~g}$ of liver were placed in $50 \mathrm{ml}$ tared beakers and frozen in liquid nitrogen. The samples were lyophilized for 40 hours at $0.5 \mathrm{~mm}$ pressure with no external heat in a Virtis Lyophilizer, Research Equipment, Gardner, N.Y.. Water content was determined as the percent loss in veight.

2. Determination of Hepatic Total Lipids

The method of isolation of total lipids was essentially that of Folch et al (1957) with modifications by Sperry and Brand (1955) and further modified by using lyophilized tissue. Lyophilized liver tissue, 19 equivalent of whole liver, was powdered with 2 glass stirring rold and mixed for $20 \mathrm{~min}$ with $20 \mathrm{ml}$ of a 2,1 chloroform-methanol mixture. The extract was suction filtered into $50 \mathrm{ml}$ centrifuge tubes and mixed with $4.0 \mathrm{ml}$ of a 0.04 percent aqueous $\mathrm{CaCl}_{2}$ solution, to remove interphase fluff. The tubes were capped and centrifuged. The upper phase was aspirated carefully to avoid losing any of the lower phase.

The inside wall of the tube was rinsed with $3.0 \mathrm{ml}$ of an upper phase solvent mixture obtained from the separation of an 8:4:3 mixture of chloroform, methanol and uater. The upper layer was then aspirated and the procedure repeated twice. The remaining extract was ciluted with methanol to form one phase and transferred to tared $50 \mathrm{ml}$ Erlenmeyer flasks. The solution was evaporated to dryness at $35-40^{\circ}$ in a stream of 
nitrogen to prevent oxidation of lipids. The residue was dryed overnight in a vacuum desicata containing dri-rite.

3. Determination of Hepatic ONA

The extraction of DNA was carried out according to the procedure of Schneider (1945), while the method of measurement was that of Burtion (1956).

One ml of whole liver homogenate was mixed with $2.5 \mathrm{ml}$ of ice-cold 10 percent trichloroacetic acid (TCA), and centrifuged. The supernatant was decanted and discarded. The residue was suspended in $2.5 \mathrm{mI}$ of TCA and centrifuged and the supernatant decanted and discarded. This procedure removed acid soluble phosphorous compounds.

The tissue residue was suspended in $1.0 \mathrm{ml}$ of water, and $4.0 \mathrm{ml}$ of 95 percent ethanol added. The mixture was centrifuged and the supernatant was decanted and discarded. The residue was resuspended in $5.0 \mathrm{ml}$ of ethanol followed by centrifugation and disposal of the supernatant. This procedure removed residual TCA. The residue was then boiled 3 times for $3 \mathrm{~min}$ each in $5.0 \mathrm{ml}$ of a $3: 1 \mathrm{mixture}$ of ethanol and ethyl ether, followed by centrifuging and discarding the supernatant to remove phospholipids.

The residue, resuspended in $1.2 \mathrm{ml}$ of water, and mixed with $1,3 \mathrm{mI}$ of cold TCA, was centrifuged and the supernatant discarded.

The residue was suspended in $5.0 \mathrm{ml}$ of 5 percent TCA, heated for $15 \mathrm{~min}$ at $90^{\circ} \mathrm{C}$, cooled and centrifuged. The super= natant was decanted and saved. The residue was resuspended in 
$2,5 \mathrm{ml}$ of 5 percent TCA, centrifuged and the supernatant decanted. The TCA extracts were combined to form a nucleic acid extract $(7.5 \mathrm{ml})$.

In the development of a chromophore, equal volumes of TCA extract and $1.0 \mathrm{~N}$ perchloric acid were mixed. To $2 \mathrm{ml}$ of this mixture was, added $2.0 \mathrm{ml}$ of diphenylamine reagent containing acetaldehyde. This reagent was prepared by dissolving $1.5 \mathrm{~g}$ of diphenylamine in $100 \mathrm{ml}$ of glacial acetic acid and adding $1.5 \mathrm{ml}$ of concentrated sulfuric acid. On the day of use, $0.1 \mathrm{ml}$ of aqueous acetaldehyde $(16 \mathrm{mg} / \mathrm{ml})$ was added for each $20 \mathrm{ml}$ of reagent required. A reagent blank was prepared containing an equal volume of 5 percent TCA and $1.0 \mathrm{~N}$ perchloric acid.

The above mixtures were incubated after capping:ait $30^{\circ} \mathrm{C}$ for 16-20 hours and read at 600 nanameters verses the reagent blank.

4. Determination of Hexobarbital Oxidation

The oxidation of hexobarbital was estimated by measuring the disappearance of substrate using the method of Cooper and Brodie (1955). One $\mathrm{m} l$ of $9,000 \times g$ supernatant was added to an incubation mixture containing 2.12 umoles of hexobarbital, 25 umoles of glucose-6-phosphate, 12.0 umoles of magnesium sulfate, 100.0 umoles of nicotinamide, 0.65 umoles of NADP and sufficient $0.1 \mathrm{~m}$ phosphate buffer, $\mathrm{pH} 7.4$, to make a final volume of $4.0 \mathrm{ml}$. Two parallel flasks, one containing $100 \mathrm{ug}$ of hexobarbital with boiled issue and the other containing tissue but not hexobarbital, were incubated at $37^{\circ} \mathrm{C}$ for $30 \mathrm{~min}$ 
and carried through the procedure to serve as blank.

The barbiturate was extracted and quantitatively measured according to a procedure described by loodie et al (1953). The above incubation mixtures were transferred to 50 ml centrifuge tubes containing 19 of sodium chloride and $30 \mathrm{ml}$ of petroleum ether (technical grade, B.P. $37-47^{\circ} \mathrm{C}$ and purified by washing with $1 \mathrm{~N} \mathrm{NaOH}, 1 \mathrm{~N} \mathrm{HCl}$ and 2 washings with water) containing 1.5 percent isoamyl alcohol. Phosphate buffer, $1.5 \mathrm{ml}$, $\mathrm{PH} 5.5$ was added. The tubes were capped, shaken for 45 min and centrifuged. Twenty $\mathrm{ml}$ aliquots of the petroleum ether layer were transferred to $50 \mathrm{ml}$ centrifuge tubes containing $10 \mathrm{ml}$ of phosphate buffer, $\mathrm{pH}$ 11.0. The tubes were capped, shaken for $10 \mathrm{~min}$ and centrifuged. The upper phase was aspirated. The absorbance of the unmetabolized barbiturate remaining in the buffer layer was determined at 245 nanometers versus $\mathrm{pH} 11$ buffer. The concentration of the unmetabolized barbiturate in the sample extract was compared with a standard solution prepared by dissolving $10 \mathrm{mg}$ of the barbiturate in sufficient distilled water to make $100 \mathrm{ml}$. A ten fold dilution was then made with $\mathrm{pH} 11$ buffer and the absorbance of the resultant solution (100 ug/ml) obtained. Recovery of the barbiturate added to the homogenate was 90-100 percent.

5. Determination of Serum Level of Hexobarbital

Rats were sacrificed by guillotine immediately upor'return of righting reflex and free flowing blood collected in conical centrifuge tubes on ice. Serum was obtained by centrifugation for 10 min in a clinical centrifuge. The extractios procedure 
of Brodie et al (1953) was performed as described in the determination of hexobarbital oxidation except that $2 \mathrm{ml}$ of serum, and $4 \mathrm{ml}$ of $\mathrm{pH} 11$ buffer was used.

6. Determination of Aminopyrine $\mathrm{N}$-Demethylase

The $\mathrm{N}$-demethylation of aminopyrine was estimated by measuring the formation of formaldehyde according to the method of McMahon and Easton (1962).

One $\mathrm{ml}$ of $9,000 \times g$ supernatant was added to an incubation mixture containing 10 umoles of aminopyrine, 45 umoles semicarbazide, 15 umoles glucose-6-phosphate, 2 umoles NADP, 50 umoles magnesium chloride, 50 umoles nicotinamide and sufficient $0.1 \mathrm{~m}$ phosphate buffer, $\mathrm{PH} 7.4$, to make a total volume of 5.0 ml. Parallel incubation flasks containing 1.32 umoles of formaldehyde (standard) in place of substrate and distilled water (blank) in place of substrate were carried through the entire procedure. Incubation was carried out at $37^{\circ} \mathrm{C}$ for 60 min. A second experiment was performed in which the incubation period was altered.

The samples were asisayed for formaldehyde in the following manner. The flask contents were poured into $15 \mathrm{ml}$ centrifuge tubes containing $4.0 \mathrm{ml}$ of 10 percent zinc chloride solution prepared with $\mathrm{CO}_{2}$-free water. After mixing, $2.0 \mathrm{ml}$ of a saturated solution of barium hydroxide was added and the samples were again mixed. The tubes were centrifuged for $10 \mathrm{~min}$ and $5.0 \mathrm{ml}$ aliquots of clear supernatant were transferred to 15 ml centrifuge tubes containing $2.0 \mathrm{ml}$ of double strength Nash reagent $(0.04 \mathrm{~m}$ acetylacetone in $0.4 \mathrm{~m}$ ammonium acetate- $0.1 \mathrm{~m}$ 
acetic acid). The contents were mixed and the tubes heated in a water bath at $60^{\circ} \mathrm{C}$ for $30 \mathrm{~min}$. Absorbance was determined at 410 nanometers versus a tissue blank. The amount of formaldehyde formed was determined by comparison with the absorbance of standards.

7. Determination of P-Chloro-N-methylaniline N-Demethylation Determination of $\mathrm{P}$-chloro-N-methylaniline (PCMA) was determined by assaying of p-chloroaniline formed according to the procedure of Kupfer and Bruggeman (1966) as modified by Fuller et al (1969). Incubations were carried out at $37^{\circ} \mathrm{C}$ for 30 min in media containing 3 umoles PCMA, 1.6 umoles NADP, 16 umoles glucose-6-phosphate, 30 umoles $\mathrm{MgCl}_{2}, 20$ umoles nicotinamide, 120 umoles phosphate buffer, $\mathrm{pH} 7,4$, and 9,000 x g rat liver supernatant containing 2-4 mg protein. The reaction was stopped by the addition of $3.0 \mathrm{ml}$ p-dimethylaminobenzaldehyde $\left(20 \mathrm{mg} / \mathrm{ml}\right.$ in $\left.1 \mathrm{~N} \mathrm{H}_{2} \mathrm{SO}_{4}\right)$. Incubation flask contents were mixed and centrifuged at $8,000 \times g$ for $30 \mathrm{~min}$. Absorbances were read at 445 nanometers and were corrected for absorbance of blanks. The amount of p-chloroaniline formed was determined by comparison with standard solutions of p-chloroaniline.

8. Determination of 0-Ethyl,0-(4-nitrophenyl)phenylphosphonothioate Detoxification and P-Nitroanisole D-Demethylation

The detoxification of 0-ethyl, 0-(4-nitrophenyl)phenylphosphonothioate (EPN) and the 0-demethylation of p-nitroanisole was estimated by measuring the formation of p-nitrophenol according to the method of Neal and DuBois (1965), as 
suggested by Netter and Seidel (1965).

To an incubation mixture containing 1.3 umoles NADP, 3.3 umoles glucose-5-phosphate, $0.2 \mathrm{ml}$ EFN-buffer and sufficient water to make a total volume of $0.8 \mathrm{ml}$ was added 0.1 or 0.2 ml of $9,000 \times 9$ supernatant, diluted 1:1 with 1.15 percent KCl containing 0.25 percent nicotinamide. The EPN-buffer was perpared by dissolving EPN, 2.0 mmoles in $1: 4$ ethanol, propylene glycol and adding $0.5 \mathrm{ml}$ of this solution to $5 \mathrm{ml}$ of $0.1 \mathrm{~m}$ phosphate buffer, $\mathrm{pH} 7.8$.

Incubation was carried out at $37^{\circ} \mathrm{C}$ for $60 \mathrm{~min}$. The reaction was terminated by adding $2.5 \mathrm{ml}$ cold acetone to the reaction flask. The flask contents were poured into centrifuge tubes and $0.2 \mathrm{ml}$ glycine-NaOH buffer $(0.5 \mathrm{~m}, \mathrm{pH} 9.5)$ was added. The tubes were centrifuged and the suparnatant read at 410 nanometers versus blank to which tissue had been added at the termination of incubation. The amount of p-nitrophenol formed was determined by comparison with the absorbance of blanks.

The procedure for measuring 0-demethylation of p-nitroanisole was the same as above except that p-nitroanisole, 0.9 mmoles was substituted for EPN.

9. Estimation of Protein

Protein content was determined by the colorimetric procedure of Lowrey et al (1951) with minor madifications. 'An aliquot of $0.4 \mathrm{ml}$ of microsomal fraction of an aliquat of 0.2 ml of 9,000 x 9 supernatant was added to a $15 \mathrm{ml}$ tast tube containing $10 \mathrm{ml}$ of $0.5 \mathrm{~m} \mathrm{NaOH}$. The tubes were heated in a water bath at $60^{\circ} \mathrm{C}$ for a complete dissolution. Stariard 
solutions of crystallin bovine serum albumin and a blank of $0.5 \mathrm{~m}$ sodium hydroxide were carried through the entire procedure. When dissdution was complete, a $0.3 \mathrm{ml}$ aliquot was removed and placed into a tube containing $1.0 \mathrm{ml}$ of $0.5 \mathrm{~m} \mathrm{NaOH}$. To this was added $5 \mathrm{ml}$ of reagent "A" (prepared by the addition of 1.0 $\mathrm{ml}$ of 1 percnet, cupric sulfate solution and $1.0 \mathrm{mll}$ of 2.7 percent potassium tartrate solution to $100 \mathrm{ml}$ of 2 percent sodium carbonate solution). After mixing, the tubes were allowed to stand at room temperature for $20 \mathrm{~min}$. At this time, $0,5 \mathrm{ml}$ of reagent "B". (prepared by diluting commercial folinphenol reagent solution with an equal volume of distilled water) was added to each sample and mixed. The samples were allowed to stand at room temperature for $40 \mathrm{~min}$ to develop color. The absorbance of the solution was determined at 500 nanometers versus a reagent blank. The concentratian of protein was. determined by camparison of this absorbance with that of standards.

10. Determination of L-Tryptophan Pyrrolase Activity L-tryptophan pyrrolase activity was estimated through assay of kynurenine formed according to the method of Knox and Mehler (1950).

Incubations were carried out at $37^{\circ} \mathrm{C}$ for $60 \mathrm{~min}$ in media containing 7.5 mmoles L-tryptophan, $2.0 \mathrm{ml}$ of $0.1 \mathrm{~m}$ phosphate buffer, $\mathrm{pH} 7.0$, and $9,000 \times \mathrm{g}$ supernatant fraction containing 10-20 $\mathrm{mg}$ of protein in a total volume of $4.0 \mathrm{ml}$.

The reaction was stopped by the addition of $2.0 \mathrm{ml}$ of $\$ 5$ percent metaphosphoric acid. The flask contents were 
centrifuged, and a $3.0 \mathrm{ml}$ aliquot was neutralized with $1.0 \mathrm{ml}$ of $1 \mathrm{~N} \mathrm{NaOH}$. The samples were read at 365 nanometers versus a blank. The amount of kynurenine formed was calculated from the molar extinction coeffecient of $4.53 \times 10^{3}$.

11. Determination of NADPH-Cytochrome c Reductase Activity NADPH-cytochrome c reductase activity was determined according to the procedure of Dahlner (1963), from the rate of reduction of cytochrome c through assay of the optical density of the reduced cytochrome at 550 nanometers at $30^{\circ} \mathrm{C}$.

Three ml of reaction mixture containing 0.65 umoles NADPH and 0.5 unoles cytochrome $c$ in $0.33 \mathrm{~mm}$ KCN-phosphate buffer (0.5 M, $\mathrm{PH} 7.4$ ) were placed in the reference and sample cuvettes. The reaction was started by adding $0.1 \mathrm{ml}$ of microsomal suspension containing 1-2 mg protein/ml to the sample cuvette. The contents were mixed and recording was started immediately. The reaction rate was linear for $3-5 \mathrm{~min}$.

The amount of cytochrome reduced was calculated from the molar extinction coefficient of $18.5 \times 10^{3}$ for the reduced minus the oxidized cytochrome c.

12. Determination of CO-Binding Pigment ( - -450 ) Concentrations The determination of $\mathrm{P}-450$ concentrations was based on the recording of a differenze spectrum generated by microsomes treated with carbon monoxide as specified by Dahlner (1963).

A reaction mixture of $6.0 \mathrm{ml}$ was prepared containing 10$20 \mathrm{mg}$ of microsomal protein and $0.05 \mathrm{~m}$ phosphate buffer, $\mathrm{pH} 7.4$, to which sodium dithionite, $1 \mathrm{mg} / \mathrm{ml}$, had been added to reduce the microsomal pigments. Three ml of the reaction mixture was 


\section{RESULTS}

Physical Parameters of Liver Enlargement

For characterizing the physical aspects of liver enlargement, rats were administered pyrethrum, $200 \mathrm{mg} / \mathrm{kg} /$ day orally for 23 days and sacrificed 24 hours subsequent to the last administered dose. The effects of pyrethrum on relative liver weights, water concentrations and total lipids are shown in Table 1.

Relative liver weights of the pyrethrum treated animals increased 23 percent as compared to controls, while body weights and hepatic water concentrations were unaffected by the treatment. Although the increase in total lipids is statistically significant at the $P=.05$ level, it does not account for the total increase in liver weight.

In Table 2 are shown the effects of pyrethrum administered for 13 days at $200 \mathrm{mg} / \mathrm{kg} /$ day on relative liver weights, protein and DnA concentrations. Relative liver weights of the pyrethrum treated animals were increased 30 percent over that of controls. Although the body weight of the pyrethrum treated animals was statistically greater at the $P=.01$ level, it dosen't completely account for the increase in liver weights, since the relative liver weights were significantly greater. Protein concentrations of whole liver homogenates, $9,000 \times g$ supernatants and $105,000 \times g$ pellets were not 
TABLE 1. Effect of pyrethrum, $200 \mathrm{mg} / \mathrm{kg} /$ day orally for 23 days, on liver to body weight ratio, total Iipid and water content

\begin{tabular}{lccc}
\hline & $\frac{\text { Mean } \pm \text { SE }(N)}{\text { Control }}$ \\
\hline $\begin{array}{l}\text { Body Weight }(g) \\
\text { Liver Weight (g) }\end{array}$ & $325.0 \pm 10.0(6)$ & $316.0 \pm 8.0 \quad$ (6) \\
\hline $\begin{array}{l}\text { Body Weight (kg) } \\
\text { Percent Water }\end{array}$ & $42.2 \pm 0.5(6)$ & $52.1 \pm 1.8 *$ (6) \\
$\begin{array}{l}\text { Total Lipids } \\
\text { mg/g liver }\end{array}$ & $63.9 \pm 0.4(6)$ & $62.7 \pm 0.9 \quad$ (6) \\
\hline
\end{tabular}

$* p \leqslant 0.05, * * p \leqslant 0.01$ as compared to control values, 
TABLE 2. Effect of pyrethrum, $200 \mathrm{mg} / \mathrm{kg} /$ day orally for 13 days, on liver to body weight ratio, protein and DNA

\begin{tabular}{|c|c|c|c|c|c|c|}
\hline \multirow[b]{3}{*}{ Body Weight $(g)$} & \multicolumn{5}{|c|}{ mean $\pm S E(N)$} & \\
\hline & \multicolumn{3}{|c|}{ Control } & \multicolumn{3}{|c|}{ Treated } \\
\hline & 147.0 & \pm 2.9 & $(8)$ & 163.7 & \pm 2.9 & ** (6) \\
\hline$\frac{\text { Liver Weight (g) }}{\text { Body We1ght (kg) }}$ & 46.0 & \pm 0.9 & $(8)$ & 59.8 & \pm 1.3 & $* *(6)$ \\
\hline $\begin{array}{c}\text { Protein (mg/g liver) } \\
\text { whole homogenate }\end{array}$ & 99.8 & \pm 3.3 & $(7)$ & 99.7 & \pm 1.5 & $(6)$ \\
\hline $9,000 \times 9$ supernatant & 70.5 & $\pm 1 \cdot 6$ & $(7)$ & 71.1 & \pm 2.4 & (6) \\
\hline $105,000 \times 9$ pellet & 18.9 & \pm 0.7 & (6) & 19.7 & \pm 0.7 & $(6)$ \\
\hline DNA (OD ${ }_{G O 0} / 9$ liver) & 1.82 & \pm 0.15 & $(7)$ & 1.30 & \pm 0.02 & $2 * *(6)$ \\
\hline
\end{tabular}

**p $\leqslant 0.01$, as compared to control values. 
significantly different from controls. DNA concentrations dacreased by 29 percent, suggestive of hypertrophy. While a combination of hypertrophy and hyperplasiacould have yielded the same results, microscopic examination of liver sections showed a predominance of hypertrophy. Barbiturate Narcosis

In order to determine the effects of pyrethrum on hexobarbital and barbital induced narcosis, rats were administered pyrethrum, $200 \mathrm{mg} / \mathrm{kg} / \mathrm{day}$ or an equal volume of corn oil, orally for 6 days. On day ?, approximately half of each group were administered hexobarbital, $135 \mathrm{mg} / \mathrm{kg}$ intraperitoneally, while the other half of each group was given barbital, $200 \mathrm{mg} / \mathrm{kg}$ intraperitoneally. The duration of narcosis was recorded, as well as onset in the case of barbital. . Table 3 shows the results of this study.

The duration of hexobarbital narcosis was decreased by approximately 50 percent in the pyrethrum treated animals while the onset and duration of barbital narcosis was unaffected.

In earlier studies (Table 4) pyrethrum administered in isoparaffinic oil verses a corn oil treated group, caused a similar decrease in the duration of hexobarbital narcosis. Hexobarbital serum levels at return of righting reflex were measured and were not significantly different $(P=0.05)$ from control levels. In Vitro Metabolic Studies

The $9,000 \times g$ supernatant fractions of liver homogenates 
TABLE 3. Effect of pyrethrum, $200 \mathrm{mg} / \mathrm{kg} /$ day orally for 6 days, on hexobarbital and barbital induced narcosis

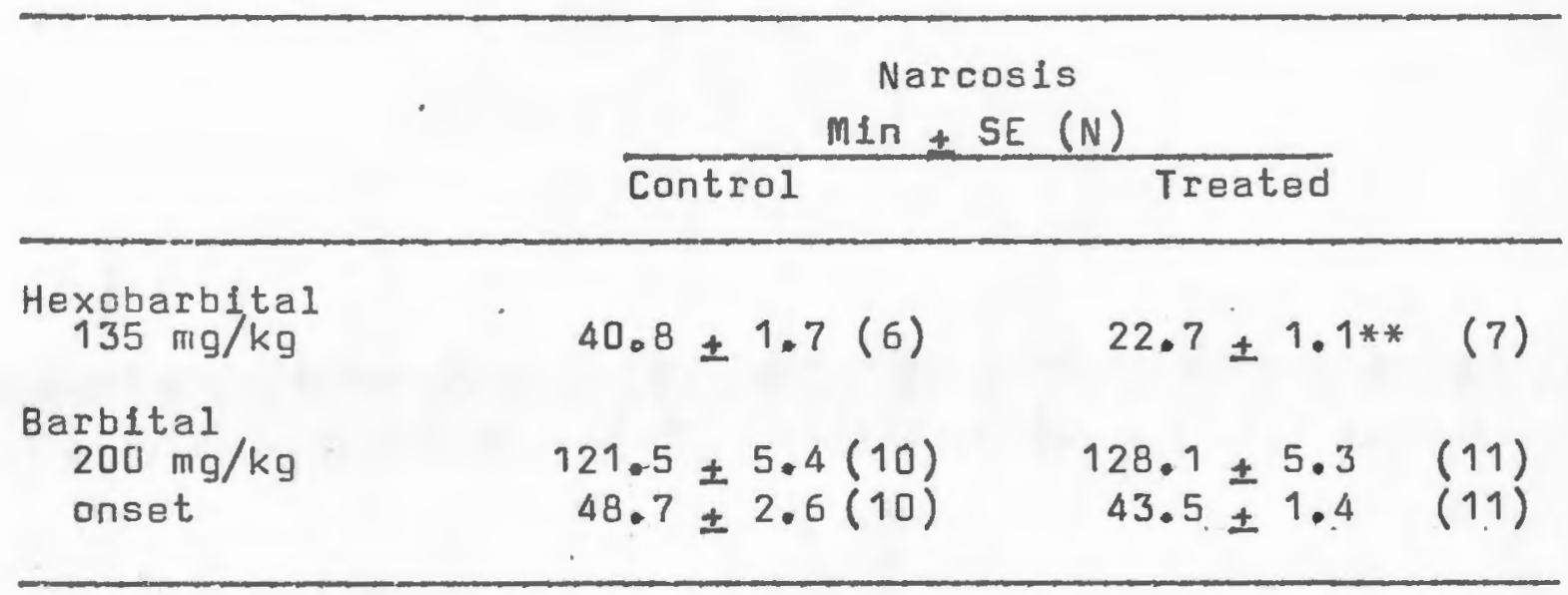

* $* P=0.01$, as comparedto control values. 
TABLE 4. Effect. of pyrethrum ${ }^{1}, 200 \mathrm{mg} / \mathrm{kg} /$ day orally for 12 days, on hexobarbital ${ }^{2}$ induced narcosis and hexobarbital serum levels at return of righting reflex

\begin{tabular}{lll}
\hline & $\frac{\text { Mean } \pm \text { SE (N) }}{\text { Control }}$ & Treated \\
\hline Narcosis (min) & $58.6 \pm 4.7(6)$ & $26.3 \pm 2.5^{*}$ (6) \\
Serum Levels (ug/ml) & $72.3 \pm 5.5(6)$ & $66.7 \pm 4.7$ (6) \\
\hline
\end{tabular}

1 Pyrethrum administered as 20 percent solution of pyrethrins in 1soparaffinic oll. Controls received an equal volume of corn oil.

${ }^{2}$ Hexobarbital, $150 \mathrm{mg} / \mathrm{kg}$ intraperitoneally. $* * p \leqslant 0.01$, as compared to control values. 
prepared from animals used in the determination of parameters of liver enlargement were employed in preliminary studies of microsomal drug metabolism. Rats that had been treated with pyrethrum, $200 \mathrm{mg} / \mathrm{kg} / \mathrm{day}$ for 23 days were examined for changes in in vitro aminopyrine demethylation and hexobarbital oxidation (Table, 5). Protein concentrations of the $9,000 \times 9$ supernatants were not significantly $(P=0.05)$ altered by the pyrethrum treatment. Hexobarbital oxidation was increased to 268 percent of control levels in the pyrethrum treated group. However, the N-demethylation of aminopyrine was not significantly altered.

Further investigation of the in vitro metabolism of aminopyrine showed the production of formaldehyde by this fraction was not linear for $60 \mathrm{~min}$ (Figure 1). However, when portions of the above prepared samples were combined and assayed in duplicate determinations for the production of formaldehyde at 10,20 , and $30 \mathrm{~min}$ there were no significan: differences between pyrethrum treated and control animals. The production of formaldehyds was found to be linear for at least $30 \mathrm{~min}$.

In a prior study of in vitro metabolism, rats that were administered pyrethrum in isoparaffinic oil, $200 \mathrm{mg} / \mathrm{kg} / \mathrm{day}$ for 12 days, showed no aiteration in the $\mathrm{N}$-demethylation of p-chloro-N-methylaniline (Table 6). However, these same animals showed a decrease in hexobarbital induced narcosis (Table 4).

The investigation for alteraiions in in vitro drug 
TABLE 5. Effect of pyrethrum, $200 \mathrm{mg} / \mathrm{kg} /$ day orally for 23 days, on aminopyrine demethylation and hexobarbital oxidation by $9,000 \times 9$ supernatants

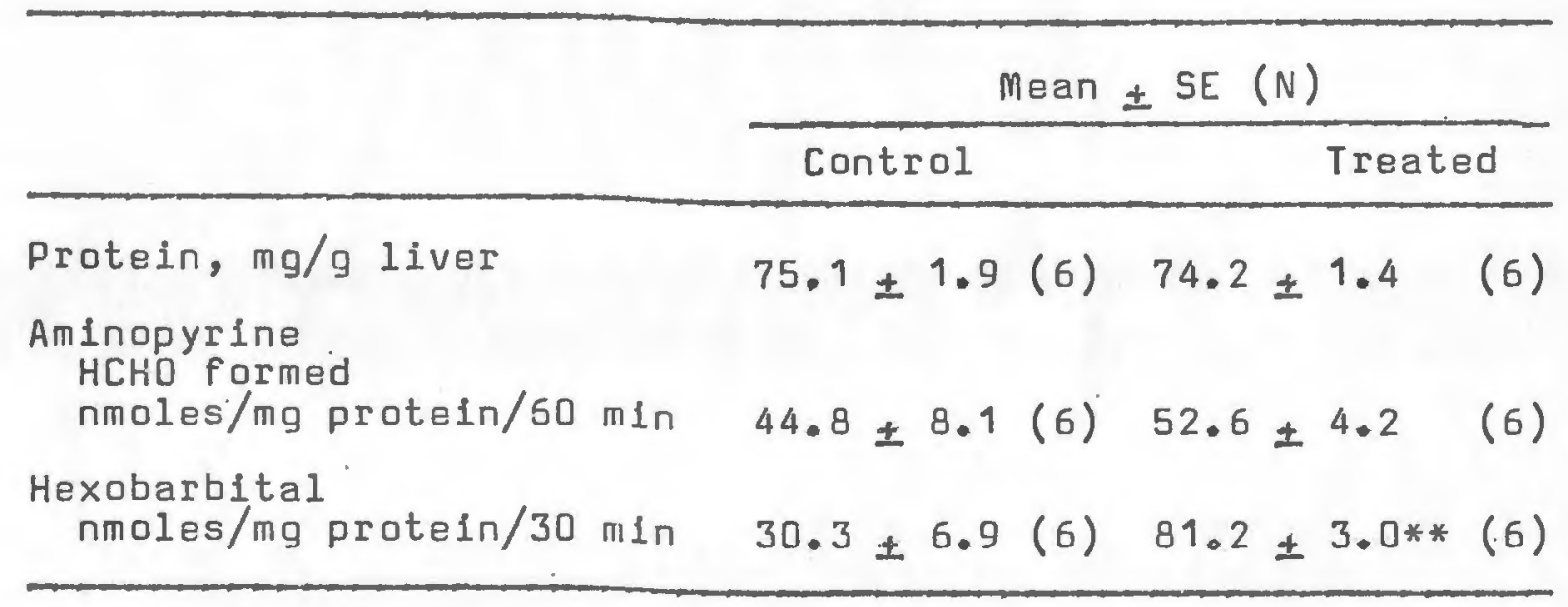

* $P=0.01$, as compared to control values. 


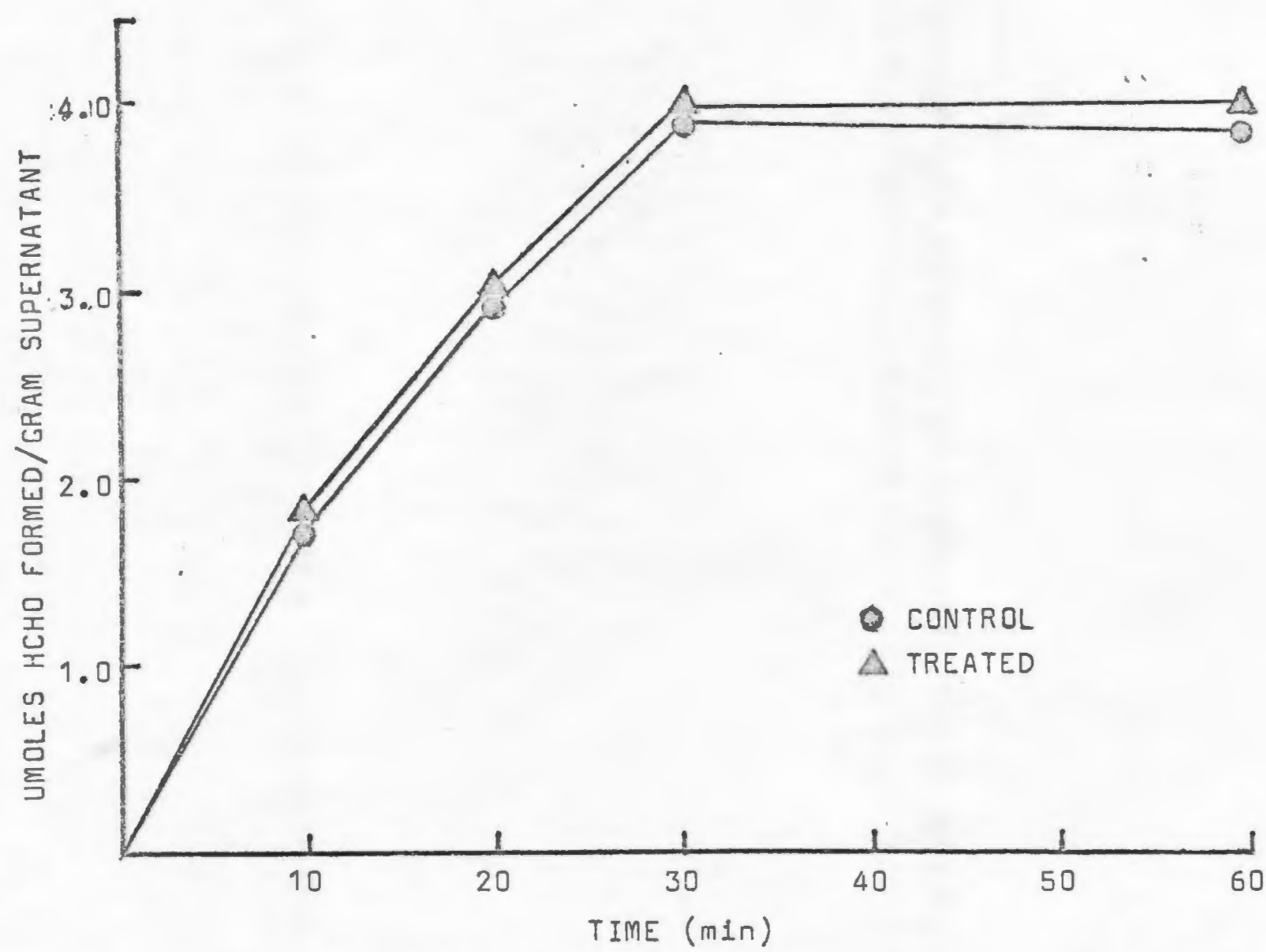

FIGURE 1. Effect of pyrethrum, $200 \mathrm{mg} / \mathrm{kg} /$ day orally for 23 days, on aminopyrine demethylation by $9,000 \times 9$ supernatants. Each point represents mean of paired samples assayed in duplicate. 
TABLE 6. Effect of pyrethrum ${ }^{9}, 200 \mathrm{mg} / \mathrm{kg} /$ day orally for 12 days, on p-chloro-N-methylaniline demethylation and aminopyrine demethylation by $9,000 \times$ g supernatants

\begin{tabular}{|c|c|c|}
\hline & \multicolumn{2}{|c|}{ Mean $\pm S E(N)$} \\
\hline & Contral & Treated \\
\hline $\begin{array}{l}\text { P-Chloro-N-methylaniline } \\
\text { p-chloroaniline farmed } \\
\text { nmoles/mg protein } / 30 \mathrm{~min}\end{array}$ & $39.5 \pm 2.6(6)$ & $50.8 \pm 5.2(B)$ \\
\hline $\begin{array}{l}\text { Aminapyrine } \\
\text { HCHO formed } \\
\text { nmoles/mg protein/60 min }\end{array}$ & $45.9 \pm 5.9(6)$ & $59.9 \pm 6.9(6)$ \\
\hline
\end{tabular}


metabolism was continued with examination of EPN detoxification, and p-nitroanisol 0-demethylation. In Table 7, rats that had been treated with pyrethrum, $200 \mathrm{mg} / \mathrm{kg} /$ day orally for 13 days, showed significant increases in the detaxification of EPN, and demethylation of p-nitroanisol, 148 and 176 percent of control levels, respectively. Hexobarbital oxidation was increased to 173 percent of control levels.

The in vitro metabolism of EPN and p-nitroanisole by $9,000 \times 9$ supernatants were chosen as indicators of microsomal drug metabolism in studies dasigned to establish a dose-effect relationship as well as the time course and reversibility of the pyrethrum caused liver changes.

In a dose-effect study, groups of 4 rats were administered pyrethrum, 85,200 or $500 \mathrm{mg} / \mathrm{kg} /$ day for 15 days. An additional group of animals was administered corn oil. Figure 2 graphically relates the information from the tables and shows the results of this study.

As shown in Table 8, in comparison to control levals, administration of $85 \mathrm{mg} / \mathrm{kg}$ of pyrethrum caused no significant liver enlargement, while 200 and $500 \mathrm{mg} / \mathrm{kg}$ causad 24 and 37 percent increases. Protein concentrations of whole liver homogenates, 9,000 $\times \mathrm{g}$ supernatants, and 105,000 $\times \mathrm{g}$ pellets were not significantly different from controls at all dosages (Table 9). As seen in Table 10, the metabolism of EPN and

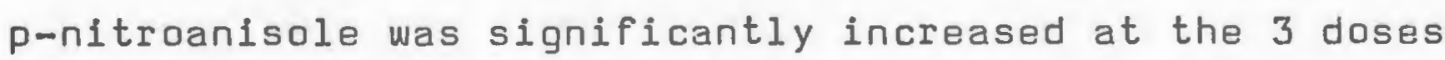
used in the pyrethrum treated animals. With increasing dosage, the metabolism of EPN was increased to 124,140 or 
TABLE 7. Effect of pyrethrum, $200 \mathrm{mg} / \mathrm{kg} /$ day orally for 13 days, on EPN detoxification, p-nitroanisole demethylation and hexobarbital oxidation by $9,000 \times 9$ supernatants

\begin{tabular}{|c|c|c|}
\hline & \multicolumn{2}{|c|}{ mean $\pm S E(N)$} \\
\hline & Control & Treated \\
\hline $\begin{array}{l}\text { EPN } \\
\text { pmitrophencl formed } \\
\text { nmoles/mg protein/60 min }\end{array}$ & $13.4 \pm 1.4(4)$ & $19.8 \pm 1.4 * *(5)$ \\
\hline $\begin{array}{l}\text { P-Nitroanisole } \\
\text { p-nitrophenol formed } \\
\text { nmoles mg protein } 60 \mathrm{~min}\end{array}$ & $16.5 \pm 1.3(4)$ & $29.0 \pm 2.2 * *(5)$ \\
\hline $\begin{array}{l}\text { Hexobarbital } \\
\text { nmoles/mi protein/30 min }\end{array}$ & $27.6 \pm 2.0(7)$ & $4.7 .7 . \pm 2.9 * *(6)$ \\
\hline
\end{tabular}

**P $\leqslant 0.01$, as compared to control values. 
TABLE 8. Effect of pyrethrum, three dose levels orally for 15 days, on body weight and liver to body weight ratio

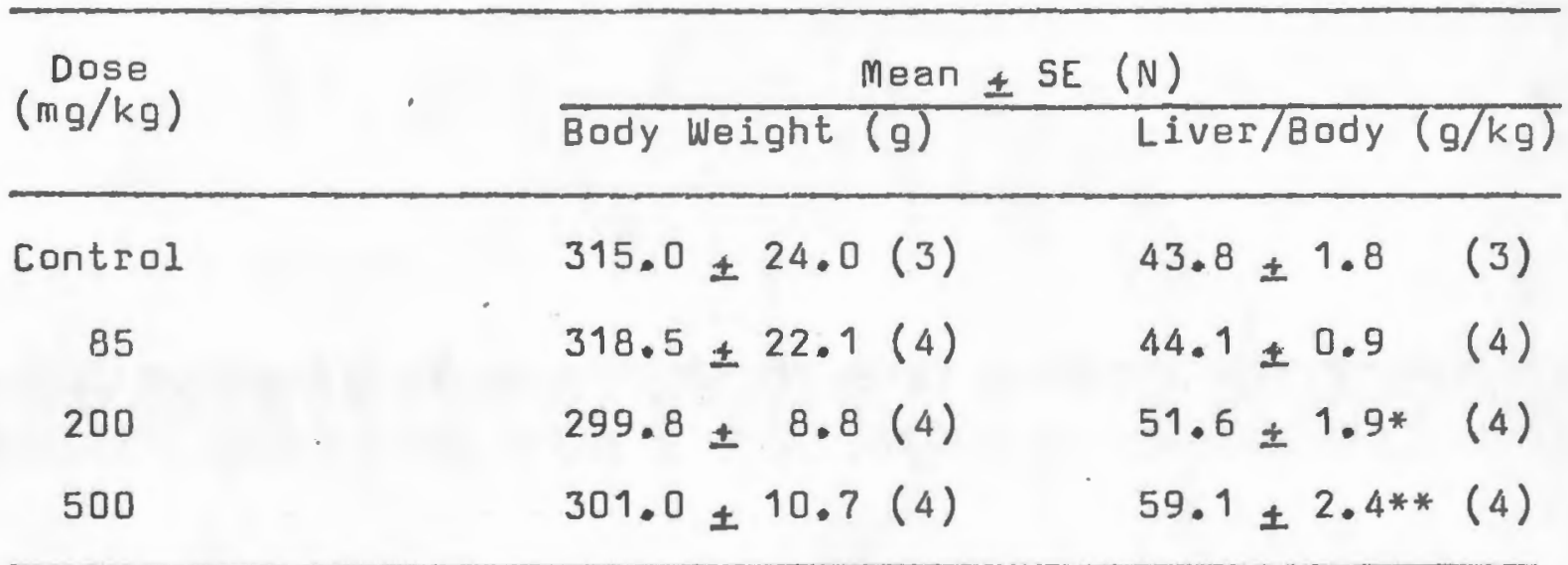

$* P \leqslant 0.05, * * P \leqslant 0.01$ as compared to control values. 
TABLE 9. Effect of pyrethrum, three dose levels orally for 15 days, on liver protein concentrations

\begin{tabular}{|c|c|c|c|}
\hline Fraction & $\begin{array}{c}\text { Dose } \\
(\mathrm{mg} / \mathrm{kg})\end{array}$ & $\begin{array}{l}\text { Protein } \\
\mathrm{mg} / \mathrm{g} \text { liver } \pm \mathrm{SE}\end{array}$ & (N) \\
\hline \multirow[t]{4}{*}{ Whole Homogenate } & Control & $110.4 \pm 5.3$ & (3) \\
\hline & 85 & $119.6 \pm 1.8$ & (4) \\
\hline & 200 & $115.6 \pm 1.9$ & (4) \\
\hline & 500 & $123.5 \pm 2.0$ & (4) \\
\hline \multirow[t]{4}{*}{$9,000 \times 9$ Supernatant } & Control & $70.2 \pm 0.6$ & (3) \\
\hline & 85 & $72.6 \pm 2.8$ & (4) \\
\hline & 200 & $70.0 \pm 1.5$ & (4) \\
\hline & 500 & $75.3 \pm 1.1 * *$ & (4) \\
\hline \multirow[t]{4}{*}{$105,000 \times 9$ Pellet } & Control & $15.5 \pm 0.7$ & (3) \\
\hline & 85 & $14.0 \pm 0.3$ & (4) \\
\hline & 200 & $13.8 \pm 0.9$ & (4) \\
\hline & 500 & $15.5 \pm 0.6$ & (4) \\
\hline
\end{tabular}

**P $\leqslant 0.01$ as compared to control values. 
TABLE 10. Effect of pyrethrum, three dose levels orally for 15 days, on the detoxification of EPN and demethylation of p-nitroanisole by $9,000 \times g$ supernatants

\begin{tabular}{|c|c|c|}
\hline $\begin{array}{c}\text { Dose } \\
(\mathrm{mg} / \mathrm{kg})\end{array}$ & $\begin{array}{l}\text { p-nitrophenol } \\
\text { nmoles/mg protein/60 } \\
\text { EPN }\end{array}$ & $\begin{array}{l}\text { formed } \\
\text { min } \pm S E(N) \\
\text { P-Nitroanisole }\end{array}$ \\
\hline Control & $9.2 \pm 0.4$ (3) & $7.5 \pm 0.5 \quad$ (3) \\
\hline 85 & $11.4 \pm 0.8 * \quad(4)$ & $10.1 \pm 0.6 *$ (4) \\
\hline 200 & $12.9 \pm 0.4 * *(4)$ & $13.9 \pm 1.2 * *(4)$ \\
\hline 500 & $16.0 \pm 1.2 * *(4)$ & $15.9 \pm 1.3 * *(4)$ \\
\hline
\end{tabular}

*P $\leqslant 0.05, * * P \leqslant 0.01$ as compared to control values. 


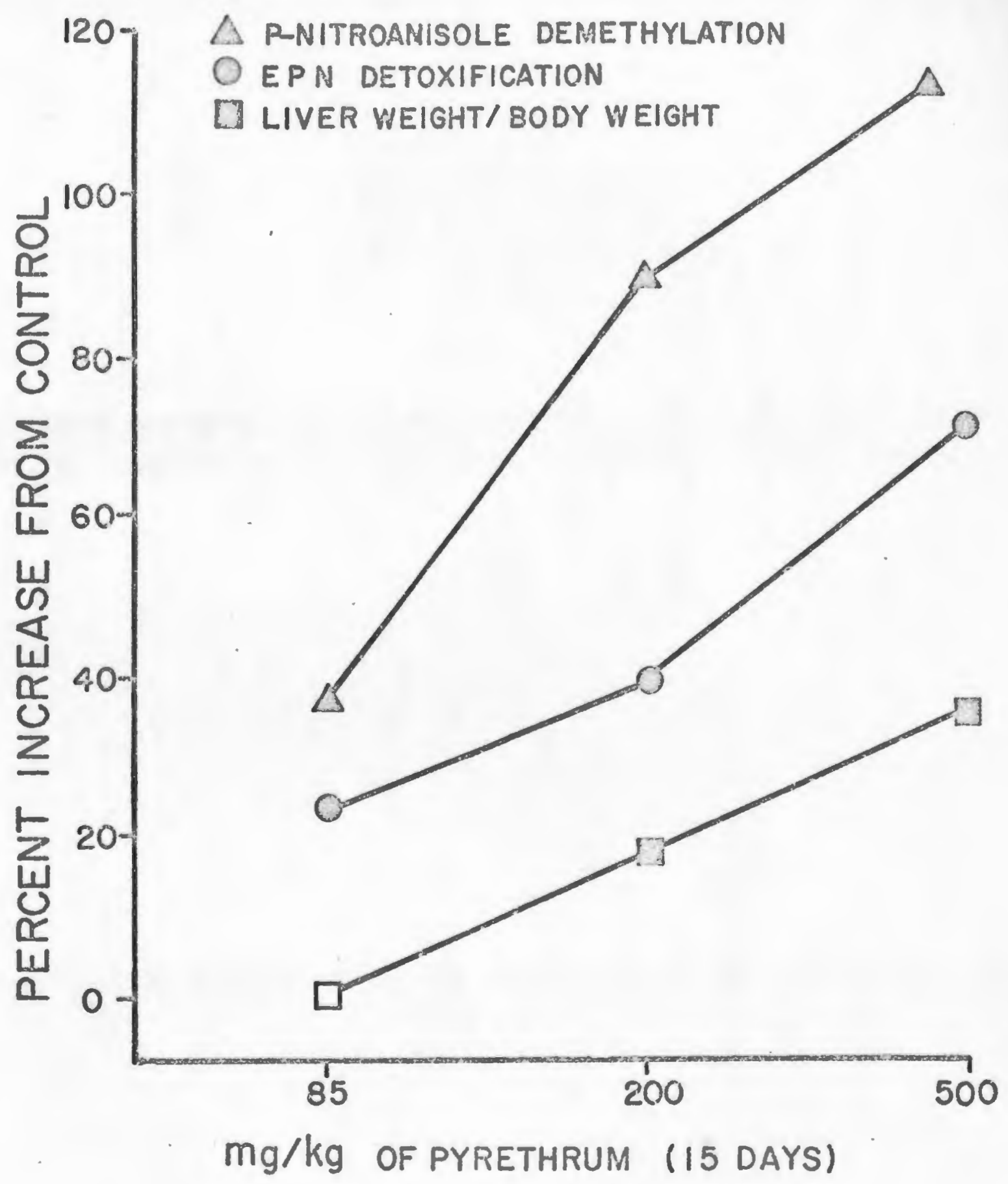

FIGURE 2. Composite Graph: Effect of pyrethrum, three dose levels orally for 15 days, on the liver to body weight ratio, detoxification of EPN and demethylation of p-nitroanisole by $9,000 \times \mathrm{g}$ supernatants. Closed symbols represent significance from control at $P \leqslant 0.05$ or $\rho \leq 0.01$. 
174 percent of contrals while the metabolism of p-nitro-. anisole was increased to 136,187 or 213 percent of controls. Figure 2 shows that with increasing dosage, these parameters increased in an approximately logarithmic fashion.

In order to examine the time course and reversibility of these changes, groups of 4 rats were administered. pyrethrum, $500 \mathrm{mg} / \mathrm{kg} /$ day for 4,7 and 17 days and sacrificed 24 hours subsequent to the last administered dose. An additional group was treated for 17 days and sacrificed on the 24 th day. Tables 11 to 13 and Figure 3 show the results of this study As seen in Table 11, with increasing duration of treatment, relative liver weights of the pyrethrum treated animals were increased to 148,158 or 160 percent of control levels after 4, 7 or 17 days of treatment, respectively. However, within 7 days following cessation of the 17 day treatment, the relative liver weights of these animals returned to control levels.

The $2 n$ vitro metabolism of Epn and p-nitroanisole was significantly increased in these animals as compared to controls. As illustrated in Table 12 and 13, the greatest increases in enzyme activity occurred within the first four days of treatment. EPN metabolism was maximum on the 8 th day, where it was 185 percent of control, and had decreased somewhat by the 17 th day to 169 percent of control. Return to control levels occurred within 7 days of cessation of treatment. p-Nitroanisole metabolism increased continually throughout the period of treatment (Table 13), and did not 
TABLE 11. Effect of pyrethrum, $500 \mathrm{mg} / \mathrm{kg} /$ day orally, on liver weight to body weight ratio

\begin{tabular}{cccc}
\hline $\begin{array}{c}\text { Days of } \\
\text { Treatment }\end{array}$ & $\begin{array}{c}\text { Day of } \\
\text { Sacirifice }\end{array}$ & $\frac{\text { Liver/Body }(\mathrm{g} / \mathrm{kg}) \pm S E(N)}{\text { Control }}$ & Treated \\
\hline 4 & 5 & $51.4 \pm 1.4(4)$ & $75.9 \pm 0.3 * *(4)$ \\
7 & 8 & $46.9 \pm 0.6(4)$ & $74.0 \pm 1.0 *$ (4) \\
17 & 18 & $47.2 \pm 0.8(4)$ & $75.4 \pm 1.9 * *(4)$ \\
17 & 24 & $40.5 \pm 2.0(8)$ & $38.0 \pm 0.8 \quad$ (3) \\
\hline
\end{tabular}

**P $\leqslant 0,01$, as compared to control values. 
TABLE 12. Effect of pyrethrum, $500 \mathrm{mg} / \mathrm{kg} /$ day orally, on the detoxification of EPN by $9,000 \times 9$ supernatants

\begin{tabular}{cccc}
$\begin{array}{c}\text { Days of } \\
\text { Treatment }\end{array}$ & $\begin{array}{c}\text { Day of } \\
\text { Sacrifice }\end{array}$ & $\begin{array}{c}\text { P-nitrophenol formed } \\
\text { nmoles/mg protein/60 min } \\
\text { Mean } \pm S E(N)\end{array}$ & Treated \\
\hline 4 & 5 & $8.9 \pm 0.2(4)$ & $15.2 \pm 1.2 * *(4)$ \\
17 & 8 & $11.8 \pm 0.5(4)$ & $21.9 \pm 0.9 * *$ (4) \\
17 & 18 & $9.8 \pm 0.2(4)$ & $1.6 .7 \pm 1.0 *$ (4) \\
\hline
\end{tabular}

**0 $\leqslant 0.01$, as compared to control values. 
TABLE 13. Effect of pyrethrum, $500 \mathrm{mg} / \mathrm{kg} /$ day orally, on demethylation of p-nitroanisole by $9,000 \times 9$ supernatants

\begin{tabular}{|c|c|c|c|}
\hline \multirow[t]{2}{*}{$\begin{array}{l}\text { Days of } \\
\text { Treatment }\end{array}$} & \multirow[t]{2}{*}{$\begin{array}{c}\text { Day of } \\
\text { Sácrifice }\end{array}$} & \multicolumn{2}{|c|}{$\begin{array}{c}\text { p-rittophenol formed } \\
\text { nmoles/mg protein/60 min } \\
\text { Mean } \pm S E(N)\end{array}$} \\
\hline & & Control & Treated \\
\hline 4 & 5 & $13.4 \pm 0.4 .(4)$ & $20.1 \pm 0.7 *$ (4 \\
\hline 7 & 8 & $18.9 \pm 0.9(4)$ & $30.2 \pm 3.1 *$ (4 \\
\hline 17 & 18 & $12.4 \pm 0.7(4)$ & $22.2 \pm 0.7 *$ (4 \\
\hline 17 & 24 & $.13 .7 \pm 1.0(4)$ & $14.6 \pm 1.2$ \\
\hline
\end{tabular}

**P $=0.01$, as compared to control values. 
appear to reach maximum levels on the 17 th day where it was 179 percent of controls. Return to control levels occurred within 7 days of cessation of treatment.

In order to deterine if these changes were part of a generalized increase in cellular metabolisin or were more specific, the in vitro oxidation of tryptophan was examined (Table 14). The tryptophan pyrrolase activities of $9,000 \times 9$ supernatants from livers of the 7 and 17 day treated animals were assayed and found to be not significantly different from controls $(P=0.05)$.

Components of Microsomal Electron Transport System

In order to account for the increase in microsomal drug metabolizing activity, components of the microsomal electron transport system were examined for possible increase in activity. Significant increases were found in the NADPH dependant cytochrome c reductase activity of microsomes from livers of animals employed in the time-effect study (Table 15 and Figure 3). With increasing duration of treatment, this activity was increased by 38,54 and 27 percent on day 5,7 and 17, respectively, but returned to control levels within 7 days after cessation of treatment.

Cytochrome p-450 levels of pyrethrum and corn oil treated animals were examined. Rats were treated with pyrethrum, 500 $\mathrm{mg} / \mathrm{kg} /$ day or corn oil for 4 days (Table 16). As correlates, liver to body weight ratios and microsomal drug metabolizing activities were measured. In comparison to controls, relative liver weights were increased to 141 percent while the in vitro 
TABLE 14. Effect of pyrethrum, $500 \mathrm{mg} / \mathrm{kg} /$ day orally, on the oxidation of L-tryptophan by $9,000 \times 9$ supernatants

\begin{tabular}{ccc}
$\begin{array}{c}\text { Days of } \\
\text { Treatment }\end{array}$ & \multicolumn{1}{c}{$\begin{array}{c}\text { kynurenine formed } \\
\text { nmoles/mg protein/60 min } \\
\text { Mean } \pm \text { SE (N) }\end{array}$} \\
\hline $\begin{array}{c}\text { Control Treated } \\
17\end{array}$ & $22.3 \pm 3.4(4)$ & $21.5 \pm 1.4(4)$ \\
\hline $34.1 \pm 1.7(4)$ & $33.7 \pm 1.1(4)$ \\
\hline
\end{tabular}


TABLE 15. Effect of pyrethrum, $500 \mathrm{mg} / \mathrm{kg} /$ day orally on NADPHcytachrome c reductase activity in liver micrasomes

\begin{tabular}{cccc}
$\begin{array}{c}\text { Days of } \\
\text { Treatment }\end{array}$ & $\begin{array}{c}\text { Day of } \\
\text { Sacrifice }\end{array}$ & \multicolumn{2}{c}{$\begin{array}{c}\text { nmoles/mg protein/min } \\
\text { Mean } \pm \text { SE (N) }\end{array}$} \\
\hline 4 & 5 & $88.4 \pm 6.2(4)$ & $120.8 \pm 6.8 *$ (4) \\
7 & 8 & $72.3 \pm 4.1(4)$ & $112.6 \pm 5.2 *$ (4) \\
17 & 18 & $190.9 \pm 4.8(4)$ & $241.8 \pm 11.8 *$ (4) \\
17 & 24 & $74.7 \pm 3.2(3)$ & $74.7 \pm 5.8 \quad(4)$ \\
\hline
\end{tabular}

**P $\leqslant 0.01$ as compared to control values. 


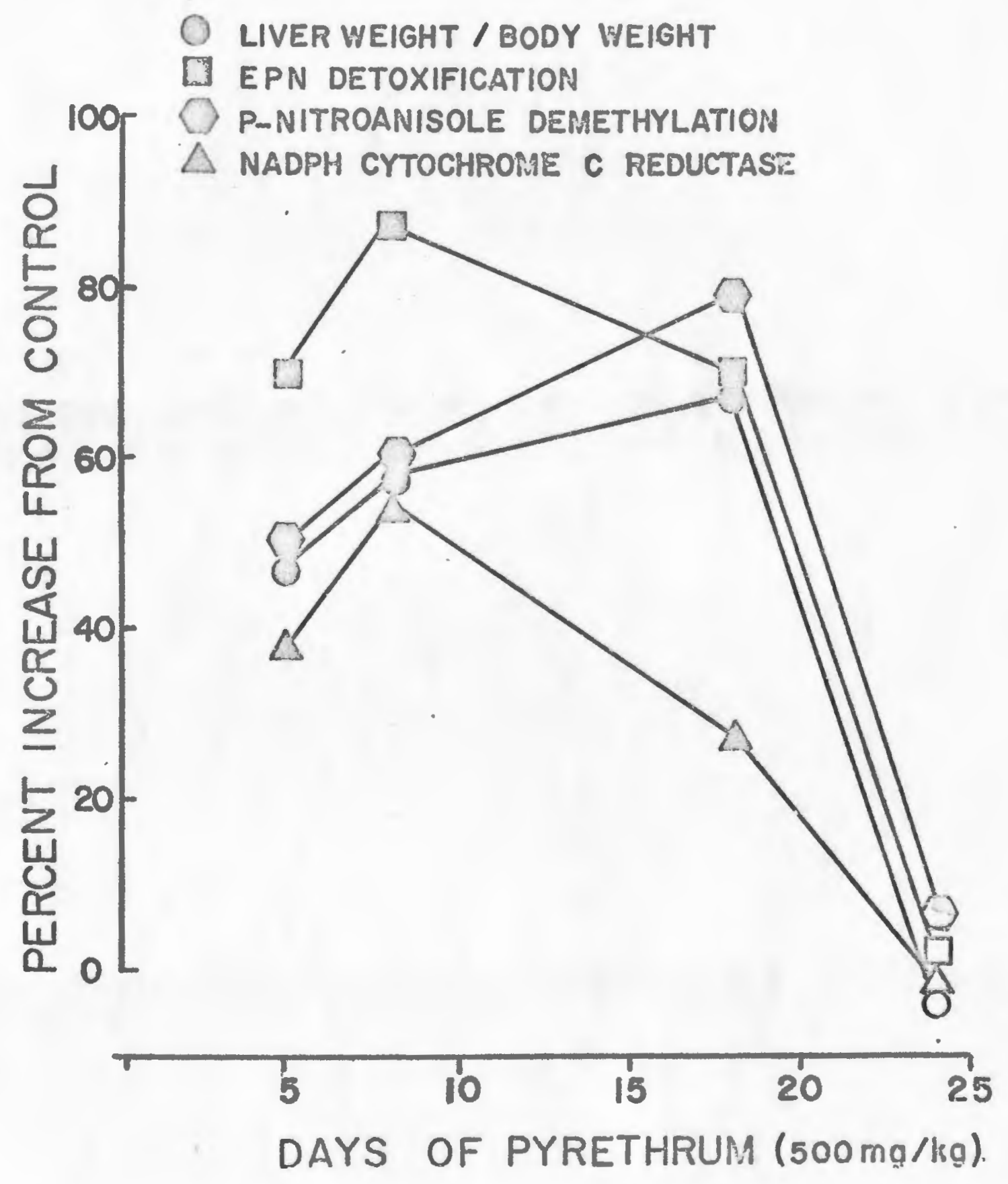

FIGURE 3. Composite Graph: Effect of pyrethrum, $500 \mathrm{mg} / \mathrm{kg} / \mathrm{day}$ orally, on the liver to body weight ratio, detoxification of EPN and demethylation of p-nitroanisole by $9,000 \times 9$ supernatants and NADPHcytochrome c reductase activity by microsomes. Closed symbols represent significance at $P \leq 0$. O5 or $p \leqslant 0.01$. 
TABLE 16. Effect of pyrethrum, $500 \mathrm{mg} / \mathrm{kg} /$ day orally for 4 days, on components of the NADPH-linked electron transport system in liver microsomes and EPN detoxification and p-nitroanisole demethylation by 9,000 $\times$ g supernatants

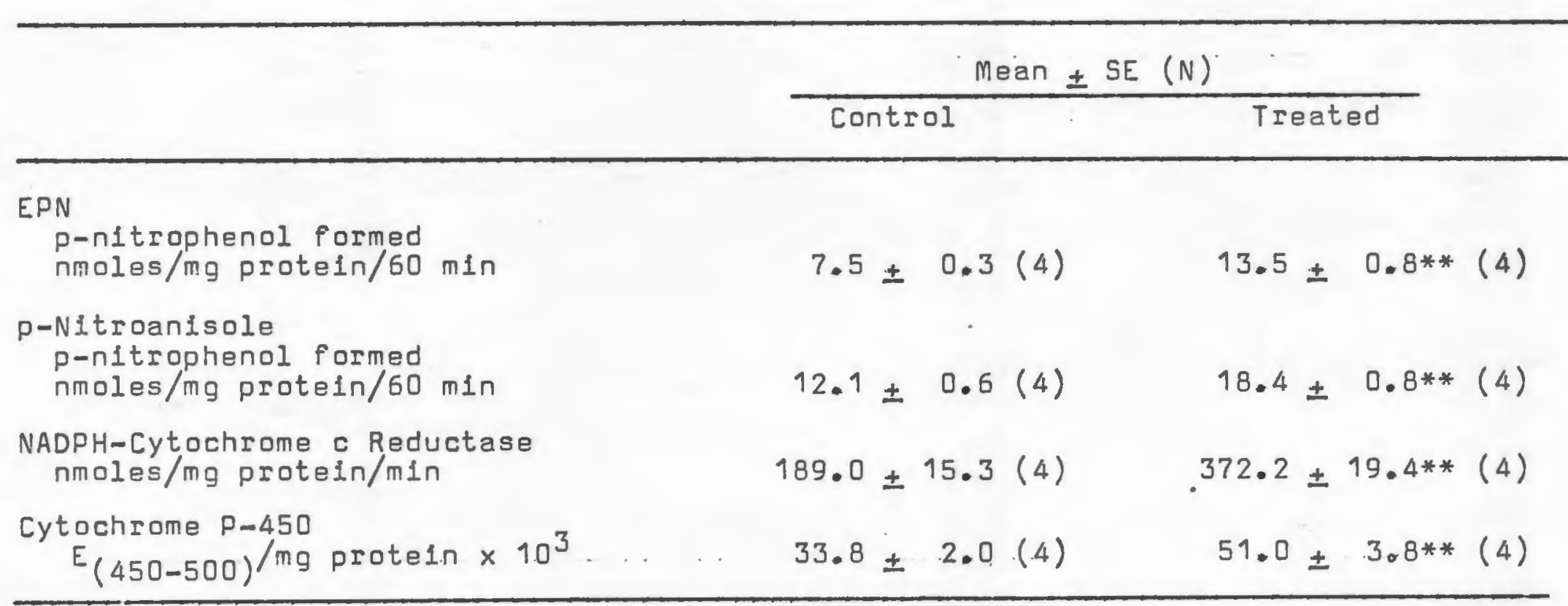

**P $\leqslant 0.01$, as compared to control values. 
metabolism of EPN and p-nitroanisole by $9,000 \times g$ supernatants was increased to 181 and $14 \mathrm{~J}$ percent, respectively. NADPH dependant cytochrome c reductase levels were increased to 197 percent of control while cytochrome P-450 levels were increased to 141 percent of controls. 


\section{DISCUSSION}

Liver enlargement due to chronic administration of drugs with varying chemical and biological characteristics is of interest not oniy for toxicological studies but also for studies of the regulation of all growth and cell division. In the absence of irreversible pathological damage, the toxicological significance of this phenomenon cannot be assessed until more is known of the essential nature of the enlargement, as well as the initial reactions, mechanisms, and the effect tha drug has on liver metabolism.

Analyses were carried out to determine if the pyrethrum induced liver weight increases were due to fat deposition, edema, proliferation of specific subcellular particles, a coordinated growth of the whole cell (true hypertrophy) or an increase in the number of cells (hyperplasia).

Control animals received a volume of corn oil vehicle equal to the total volume of pyrethrum solution administered in order to avold liver weight or body weight changes due to differences in diet.

Measurement of water and lipid concentrations (Table 1) showed that the liver weight increases were not due to fat deposition or edema. If edema or fat deposition was the principal cause of the enlargement, measurement of protein concentration of whole liver homogenates and sub-fractions 
should have indicated this through dilution of protein per unit liver. No dilution of protein concentration was observed (Table 2), while measurement of lipid and water concentrations provided direct confirmation of the lack of edema or fat deposition.

Liver fractionation provided information on the cellphysiological aspects of the enlargement. The $9,000 \times 9$. supernatant fraction contains mainly microsomes and cell sap since whole cells, debris, mitochondria and nuclei are removed by sedimentation at this centrifugal force. Microsomes were isolated by sedimentation at $105,000 \times 9$. Lack of alterations in protein concentrations of these fractions indicated that the liver weight increases were not due to proliferation of microsomes.

The question of whether hypertrophy or hyperplasia caused the increase in liver weights was examined through measurement of DNA concentrations and microscopic examination of liver sections. Increases in liver weight combined with decreases in liver DNA concentrations are indicative of cellular hypertrophy. Increases in liver DNA concentrations are suggestive of hyperplasia with a predominance of immature cells. As seen in Table 2, DNA levels were found to be decreased by approximately 30 percent on a per gram of liver basis as compared to a 30 percent Iise in total weight. Altough suggestive of hypertrophy, a mixture of hyperplasia with immature cells and hypertrophy might have yielded the same percentage changes. 
Examination of liver sections showed a predominance of enlarged cells with a slight increase in mitotic divisions and smaller, immature cells. These studies suggested that the liver weight. increases resulted primarily from a coordinated growth of the whole cell.

While the chemical constituents of the livers of treated animals and of controls were similar, one could not necessarily conclude that normal and pyrethrum induced liver grouth is identical. Whole tissue is employed in chemical determinations of various cell constituents, such as lipid and protein, and does not take into consideration functional variation of subcellular components. With normal liver growth, the increase in total protein should show a proportionally constant rise in all liver enzymes. The increase in total protein accompanying pyrethrum induced liver enlarcement was subjected to a more detailed study. Possible alterations in microsomal drug metabolism were first examined in vivo followed by examination of microsomal and cytoplasmic enzymes in vitro.

Duration of hexobarbital narcosis, which is limited by Its metabolism in hepatic microsomes (Cooper and Brodie, 1955) was decreased in pyrethrum treated animals (Table 3 ).' The onset and duration of narcosis due to barbital, which is excreted unmetabolized (Dorfman and Goldbaum, 1947; Maynert and Van Dyke, 1958: Ebert et al, 1964), was unaffected by pyrethrum pretreatment. These data suggested that the decreases in hexobarbital narcosis resulted from an increase in microsomal drug metabolism rather than alterations in central 
nervous system sensitivity. This idea was further substantiated by the lack of differences in hexobarbital serum levels at return of righting reflex in the two groups (Table 4).

The study was continued with an examination of in vitro microsomal drug metabolism in order to determine if the decreases in hexobarbital narcosis resulted only from an increased metabolic capacity of a larger liver or was combined with increases in specific enzymatic activity. Measurement of aminopyrine $\mathrm{N}$-demethylase activity was chosen as a possible indicator of altered ricrosomal drug metabolism since its metabolism is increased by two prototypes of inducing agents, 3-methylcholanthrene and phenobarbital. The N-demethylation of aminopyrine was found to be unaltered by pyrethrum treatment (Table 5). The $\mathrm{N}$-demethylation of $\mathrm{P}$-chloro-N-methylaniline was also found to be unaltered by pyrethrum treatment (Table 6).

Since the decrease in hexobarbital narcosis uithout a concomitant alteration in barbital narcosis suggested an increase in microsomal drug metabolism, even though there were no increases in the N-demethylation of p-chloromethylaniline or aminopyrine, the in vitro metabolism of hexobarbital was examined. Tables 5 and 7 show that in vitro hexobarbital oxidase activity was elevated by pyrethrum treatment.

In his review, Conney (1967) drew a distinction between the selective induction effects of the polycyclic hydrocarbons, which induce only a few activities such as zoxazolamine hydroxylase and azo dye demethylase but not hexobarbital oxidase 
or aminopyrine demethylase, and the generalized inductive effect of phenobarbital which induces all four activities. Because of these otservations, the lack of increase in aminopyrine demethylase was subjected to a more detailed study. Samples that showed no increase in aminopyrine demethylase activity when assayed for formaldehyde production at $60 \mathrm{~min}$ were pooled in pairs and in duplicate determinations, assayed for formaldehyde production at 10,20 and $30 \mathrm{~min}$. As shcwn in Figure 3, there was no significant difference between pyrethrum treated and control animals in the production of formaldehyde at 10,20 and $30 \mathrm{~min}$, although the rate was approximately linear for only $30 \mathrm{~min}$.

This work confirmed that of Soyka (1969), who noted that even if linearity for $15 \mathrm{~min}$ was accomplished, the use of too small a quantity of glucose-6-phosphate limited the production of formaldehyde. Thus the activity of adult liver erroneously appeared to be less than that from 20 day old animals if studied after $30 \mathrm{~min}$ of incubation.

The increase in hexobarbital oxidase activity withoct an increase in aminopyrine demethylase activity suggested that pyrethrum did not resemble in effects produced either prototype of enzyme inducer. It is interesting to note that in studying the structure activity relationships of substituted phenols on liver weights and liver enzymes in the rat, Gilbert et al (1969) found there was no direct relationship between liver weight increases and increases in hexobarbital oxidase and aminopyine demethylase activities. Certain compcunds 
consistently showed a greater effect on aminopyrine demethylase than on hexobarbital oxidase while the reverse also occurred. They further found that 2,6-di-tert-buty1-4-hydroxymethylphenol induced hexobarbital oxidase strongly with no corresponding increase in the activity of aminopyrine demethylase. This rew category appears to exemplify the effects of pyrethrum. In order to further categorize the effects of pyrethrum, other microsomal enzymes were examined for alteration in activity, including p-nitroanisole 0-demethylase and EPN detaxification. Table 7 shows that the activities of both of these enzymes were increased.

At this point it was of interest to determine if these increases in drug metabolizing activity were part of a generalized increase in cellular metabolic activity or were mcre specific as suggested by the lack of increase in aminopyrine $\mathrm{N}$-demethylase and $\mathrm{p}$-chloromethylaniline $\mathrm{N}$-demethylase activities. Lack of increase in tryptophan pyrrolase activity (Table 14), an enzyme localized in the $105,000 \times 9$ supernatant fraction and therefore a probable cytoplasmic enzyme, further supported the hypothesis that the enzymatic increases were specific in nature, indicative of true enzyme induction.

Investigation of liver enlargement and increases in drug metatolizing activities due to pyrethrum was continued with establishment of a dose-effect relationship (Figure 2). The results of this study indicated that increases in enzyme activity were evident before liver enlargement. Increases in enzyme activity paralleled the liver enlargement. These 
parameters increased in a logarithmic fashion with increasing dosages indicating a dose-effect relationship. The data also suggested that the maximum response of the parameters had not been reached, although higher doses are within tha lethal range of pyrethrum.

An investigation was also undertaken to sţudy the time course and reversibility of these changes (Figure 3 ). Liver enlargement and p-nitroanisole metabolism increased with increasing duration of treatment. The greatest increase occurred during the first four days of treatment, with smaller increases at the next consecutive measurements, suggesting the attainment of a plateau of peak activity after about 2 weeks of treatment. EPN detoxification and NADPH-cytochrome c reductase activity paralleled each other in activity. The greatest increase in activity occurred during the first four days, but unlike the time course of p-nitroanisole metabolism and liver enlargement, it was maximum on the 8 th day and had declined somewhat by the 18th day. Martin and Gilbert (1968) and Gilbert et al (1969) recognized that continued administration of a compound could lead to regression of the initial effect. These studies suggest that increases in liver size cannot necessarily be equated with increases in enzymatic activity.

All parameters measured, returned to control levels within 7 days after cessation of treatment showing that the changes are spoftaneously reversible upon discontinuation of exposure to pyrethrum. 
True enzyme inducers, stimulants of hepatic microsomal drug metabolism, have the ability to increase components of the microsomal electron transport system. For example, phenobarbital and 3-methylcholanthrene cause increases in P-450 concentrations, and phenobarbital increases the activity of NADPH-cytochrome c reductase (Conney, 1967). These observations suggested that pyrethrum may have a similar inductive effect on these components of the microsomal electron transport, and consequently be a true enzyrne inducer. As shown in Tables 15 and 16 and Figure 3 , both of these components are elevated by pyrethrum treatment.

It should be noted that the magnitude of the doses employed in this study would not be encountered in normal usage of pyrethrum. However, this study does not indicate a no-effect level for pyrethrum. 


\section{SUMMARY AND CONCLUSIONS}

1. Liver enlargement due to pyrethrum is associated with proportional increases in total water and total protein of whole liver, $9,000 \times 9$ supernatant fraction and 105,000 $\times 9$ pellets. Statistically significant $(P \leqslant 0.05)$ increases in total lipid per gram of liver did not account for the total increase in liver weight. The enlargement was further associated with a decrease in DNA per gram of liver, suggestive of hypertrophy. Microscopic examination of liver sections supported this hypothesis.

2. Liver enlargement due to pyrethrum is associated with a decrease in hexobarbital induced narcosis. Hexobarbital serum levels at awakening were not significantly different in control and pyrethrum treated animals. The onset and duration of barbital narcosis was not significantly altered by the pyrethrum pretreatment. These results suggested that the decrease in hexobarbital induced narcosis was due to increased microsomal metabolism of the drug rather than a change in CNS sensitivity to the drug。

3. In vitro increases in specific microsomal oxidation of hexobarbital, 0-demethylation of p-nitroanisole and detoxification of EPN were associated with the liver enlargement. The observed lack of increase in specific activity of aminopyrine demethylase did not result from the duration 
of incubation employed in the assay, although the production of formaldehyde was not linear for 60 min but linear for at least $30 \mathrm{~min}$.

4. In vitro tryptophan pyrrolase activity, a 105,000 $\times 9$ supernatant enzyme, was not significantly altered by pyrethrum treatment. The lack of increase in this enzyme, as well as the lack of increases in aminopyrine N-demethylase and p-chloromethylaniline N-demethylase, suggested that the increases in microsomal drug metabolism were not part of a generalized increase in cellular metabolism.

5. Increases in liver to body weight ratios and increases in metabolism of p-nitroanisole and of EPN by $9,000 \times 9$ supernatants were found to be dose related. At the lowast dase used of $85 \mathrm{mg} / \mathrm{kg}$, increases in microsomal drug metabolism were evident before liver enlargement. Peak activity of these parameters was not apparently reached at the highest dose used of $500 \mathrm{mg} / \mathrm{kg}$, although higher doses were within the lethal range of pyrethrum.

6. Increases in liver to body weight ratios and increases in metabolism of p-nitroanisole and of EPN by $9,000 \times 9$ supernatants were found to be time related. The greatest increases in these parameters occurred within the first four days of treatment, but did not appear to reach plateau levels simultaneously. The increase in NADPH-cytochrome c Ieductase, a component of the microsomal electron transport system, was also time related. It is important to note that all parameters measured returned to control 
levels within 7 days after cessation of treatment, suggesting that irreversible changes had not occurred.

7. Increases in P-450, a component of the microsomal electron transport system, were associated with increases in liver to body weight ratios and increases in EPN detoxification, p-nitroanisole demethylase and NADPH-cytochrome c reductase.

8. These findings are consistent with and support the hypothesis that pyrethrum caused liver enlargement results from true hypertrophy. It is proposed that increases in specific microsomal drug metabolizing activity, as well as an increase in metabolic capacity resulting from the larger liver, account for the decrease in hexobarbital induced narcosis. It is proposed that the increases in specific enzyme activity result from the synthesis of new protein and that in fact, pyrethrum is a true enzyme inducer. These data suggest the need for further investigation to reevaluate the use of pyrethrum as a non-inducing insecticide. 


\section{REFERENCES}

Addis, T. and T. Gray: Body weight and organ weight. Growth $14: 49-80,1950$.

Ambrose, A.M.: Toxicological studies on pyrethrin-type esters of chrysanthemumic acid. I. Chrysanthemumic acid, 6-chloropiperonyl ester (Barthrin). Toxicol. Applied Pharmacol. 5, 414-426, 1963 .

Ambrose, A.M.: Toxicological studies on pyrethrin-type esters of chrysanthemumic acid. II. Chrysanthemumic acid, 2,4-dimethyl benzyl ester. Toxicol. Applied Pharmacol. 6: 112-120, 1964.

Ambrose, A.M. - and D.J. Robbins: Comparative toxicity of pyrethrin and allethrin. Federation Proc. 10:276-277, 1951.

Arcos, J.C., A.H. Conney and N.P. Buu-Hoi; Induction of microsomal enzyme synthesis by polycyclic aromatic hydrocarbons of different molecular sizes. J. B1ol. Chem. 236: $1291-1296,1961$.

Berteau, P.E., J.E. Casida and T. Narahashi: Pyrethroid-like biological activity of compounds lacking cyclopropane and ester groupings. Science 161:1151-1153, 1968.

Bond, H. and J.J. DeFeo: Personal communication, 1967-1969.

Bridges, P.M.: Absorption and metabolism of $C^{14}$-allethrin by the adult housefly, Musca domestica L. Blochem. J. 66:316$320,1957$.

Brodie, B., J. Burns, P. Lief, E. Bernstein and E. Papper: The fate of pentobarbital in man and dog and a method for its estimation in biological material. J. Pharmacol. Exptl. Therap. 109:26-34, 1953.

Burton, $K_{*}$ : A study of the conditions and mechanism of the diphenylamine reaction for the colorimetric estimation of deoxyribonucleic acid. Biochem. J. 62:315-322, 1956.

Camougis, G. and W.M. Davis: A comparative study of the neuropharmacological basis of action of pyrethrins. New England Research, Inc., Worcester, Massachusetts, 1971. 
Carpenter, C.P., C.S. Weil, U.C. Pozzani and H.F. Smyth, Jr.: Comparative acute and subacute toxicities of allethrin and pyrethrins. Arch. Ind. Hyg. Occupational Med. 2:420-432, 1950.

Carpenter, C.P., C.S. Weil, U.C. Pozzani and H.F. Smyth, Jr.: Acute and subacute toxicity of cyclethrin. Arch. Ind. Hyg. Occupational med. 10:162-168, 1954.

Casida, J.E., E.C. Kimmel, M. Elliott and N.F. Janes: Oxidative metabolism of pyrethrins in mammals. Nature 230:326$327,1971$.

Chamberlain, R.W.: An investigation on the action of piperonyl butoxide with pyrethrum. Am. J. Hyg. 52:153-183, 1950.

Chang, 5.C. and C.W. Kearns: Metabolism in vivo of $C^{14}-$ labeled pyrethrin I and cinerin I by houseflies with special reference to the synergistic mechanism. J. Econ. Entomol. 57:397-404, 1964 .

Chen, Y-L. and J.E. Casida: J. Agric. Food Chem. 17:208, 1969.

Chikamoto, T.: The toxicity of chrysanthemyl-, allethronyland piperonyl piperonylates and the higher homologues. Agricultural Biol. Chem. 28:633-638, 1964.

Conney, A.H.: Pharmacological implications of microsomal enzyme induction. Pharmacol. Rev. 19:317-366, 1967.

Conney, A.H., C. Davison, R. Gastel and J.J. Burns: Adaptive increases in drug-metabolizing enzymes induced by phenobarbital and other drugs. J. Pharmacol. Exptl. Therap. 130:1-8, 1960.

Conney, A.H. and A.G. Gilman: Purcmycin inhibition of enzyme induction by 3-methylcholanthrene and phenobarbital. J. Biol. Chem. 238:3682-3685, 1963.

Cooper, J.R. and B.B. Brodie: The enzymatic metabolism of hexobarbital (Evipal). J. Pharmacol. Exptl. Therap. 114: $409-417,1955$.

Dahlner, G.: Studies on the structural and enzymatic organization of the membranous elements of liver microsomes. Acta Path. Microbiol. Scand., Suppl. 6:7, 1963.

Dorfman, A. and L.R. Goldbaum: Detoxificetion of barbiturates. J. Pharmacol. Exptl. Therap. 90:330-337, 1947.

Ebert, A.G., G.K. Yim and T.S. Miya: Distribution and metabclism of barbital $c^{14}$ in tolerant and non-tolerant rats. Biochem. Pharmacol. 13:1267-1274, 1964. 
Ellis, C.H., C.H. Thienes and C.A.G. Wiersma: The influence of certain drugs on the crustacean nerve-muscle system. Biol. Bull. 83:334-352, 1942.

Feinberg, G.M.: Pyrethrum sensitization; its importance and relation to pollen allergy. J. Am. Med. Assoc. 102:1557$1558,1934$.

Folch, J., M. Lees and G.H.S. Stanley: A simple method for the isolation and purification of total lipids from animal tissues. J. B,iol. Chem. 226:497-509, 1957. .

Fouts, J.R.: Factors influencing the metabolism of drugs in liver microsomes. Ann. N.Y. Acad. Sci. 104:875-880, 1963.

Fuller, G.C., A.M. Olshan and H. Lal: The stimulatory effect of phenobarbital on the $\mathrm{N}$-demethylation of $\mathrm{p}$-chlor o- $\mathrm{N}$-methylaniline. Life Sciences 8:383-387, 1969.

Garratt, J.R. and J.W. Bigger: Asthma due to insect powder. Brit. Med. J. 2: 761, 1923.

Gilbert, D. and L. Golberg: Liver weight and microsomal processing (drug-metabolizing) enzymes in rats treated with butylated hydroxytoluene or butylated hydroxyanisole. Biochem. J. 97:28P, 1965.

Gilbert, D., A.D. Martin, S.D. Gangolli and R. Abraham: The effect of substituted phenols on liver weights and liver enzymes in the rat: structure-activity relationships. Fd. Cosmet. Toxicol. 7:603-619, 1969.

Golberg, L.: Liver enlargement produced by drugs: its significance. Proc. Eur. Soc. Study Drug Toxicity $\underline{7}: 171-182,1966$.

Hayes, W.J., Jr.: Insecticides, rodenticides, and cther economic poisons. In: Drill's Pharmacology in Medicine. J.R. Dipalma, editor, Third Edition, McGraw-Hill, New York, 1965.

Kearns, C.W.: The mode of action of insecticides. Ann. Rev. Entomol. 1:123-147, 1956.

Kimbrough, R.D., T.R. Gaines and W.J. Hayes: Combined effect of DDT, pyrethrum, and piperonyl butoxide on rat liver. Arch. Environ. Health 16:333-341, 1968.

Knox, W.E. and A.H. Mehler: Tryptophan pyrrolase. J. Biol. Chem. 187:419-428, 1950. 
Kunz, H.W.: Biochemische Analysen der durch Pharmaka induzierten Lebervergrosserung. Nauryn-Schmiedberg's Arch. Exptl. Path. Pharmak. 247:369-383, 1964.

Kunz, W., G. Schaude, W. Schmid and M. Siess: Stimulation of liver growth by drugs. Proc. Eur. Soc. for the Study of Drug Toxicity ?:113-137, 1966.

Kupfer, D. and L.L. Bruggeman: Determination of enzymic demethylation of p-chloro-N-methylaniline. Assay of aniline and p-chloroaniline. Analyl. Biochem. 17:502-512, 1966.

Lawenstein, 0.: A method of physiological assay of pyrethrum extract. Nature 150:760-762, 1942.

Lowry, O.H., N.J. Rosebrough, A.L. Farr and R.J. Randall: Protein measurement with the folin-phenol reagent. J. Biol. Chem. 193:265-275, 1951 .

Martin, A.D. and D. Gilbert: Enzyme changes accompanying liver enlargement in rats treated with 3-tert-butyl-4-hydroxyanisole. Biochem. J. 106:22P, 1968.

Masri, M.S., F.T. Jones, R.E. Lundin, G.F. Bailey and F. DeEds: Metabolic fate of two chrysanthemumic acid esters; Barthrin and dimethrin. Toxicol. Applied Pharmacol. 6:711-715, 1964a.

Masri, M.S., A.P. Hendrickson, A.J. Cox, Jr. and F. DeEds: Subacute toxicity of two chrysanthemumic acid esters: Barthrin and dimethrin. Toxicol. Applied Pharmacol. 6:716-725, 1964b.

Maynert; E.W. and H.B. Van Dyke: The absence of localization of barbital in divisions of the CNS. J. Pharmacol. Exptl. Therap. 98:184-187, 1950.

McCord, C.P., C.H. Kilker and D.K. Minister: Pyrethrum dermatitis. A record of the occurrence of occupatioral dermatoses among workers in the pyrethrum industry. J. Am. Med. Assoc. 77: $448-449,1921$.

McMahon, R.E. and N.R. Easton: The N-demethylation of butynamine. J. Pharmacol. 135:128-133, 1962.

Metcalf, R.L.: Organic Insecticides. Their Chemistry and Mode of Action. Wiley (Interscience), New York, 1955.

Narahashi, T.: Effects of the insecticide allethrin on membrane potentials of cockroach giant axons. J. Cell. Comparative Physiol. 59:61-65, 1962a. 
Narahashi, T.: Nature of the negative after-potential increased by the insecticide allethrin in cockroach giant axons. J. Cell. Comparative Physiol. 59:67-76, 1962b.

Narahashi, T. and N.C. Anderson: Mechanism of excitation block by the insecticide allethrin applied externally and internally to squid giant axons. Toxicol. Appl. Pharmacol. 10:529-547, 1967,

Neal, R.A. and K.P. DuBois: Studies on the mechanism of detoxification of cholinergic phosphorothioates. J. Pharmacol. Exptl. Therap. 148:185-192, 1965.

Negherbon, W.0.: Handbook of Toxicology. Vol. III: Insecticides. Saunders, Philadelphia, 1959.

Netter, K.J. and G. Seidel: An adaptively stimulated 0-demethylating system in rat liver microsomes and its kinetic properties. J. Pharmacol. Exptl. Therap. 146:61-73, 1964.

Nishizawa, Y. and J. Casida: Synthesis of d-trans-chrysanthemumic acid-1-c 14 and its antipcde on a semimicro scale. J. Agr. Food Chem. 13:525-527, 1965.

O'Brien, R.D.: Insecticides. Action and Metabolism. Academic Press, New York, 1967.

Office of the Surgeon.General: Pyrethrum Extract; Chronic dermal toxicity; Vapor toxicity. Supplement to report dated July 25, 1951. Office of the Surgeon General, Department of the Army. 17 pp. September 11, 1951.

Office of the Surgeon General: Pyrethrum Extract; Histopathology. Supplement to reports dated July 25, September 11, and December 10, 1951. Office of the Surgeon General, Department of the Army. 21 pp. March 10, 1952.

Roeder, K.D. (Editor): Insect Physiology. Wiley (Interscience), New York, 1953.

Schallek, W. and C.A.G. Wiersma: The influence of various drugs on a crustacean synapse. J. Cell. Comparative Physiol. 31: 35-47, 1948 .

Schneider, W.C.: Phosphorous compcunds in animal tissues. I. Extraction and estimation of desoxypentose nucleic acid and of pentose nucleic acid. J. Biol. Chem. 161:293-303, 1945,

Setnikar, I. and M.J. Magistretti: Relationships between organ weight and body weight in the male rat. Arzneimittelforsch. 15:1042-1048, 1965. 
Shepard, H.H.: The Chemistry and Toxicology of Insecticides. Burgess Publishing Co., Minneapolis, 1939.

Shepard, H.H.: The Chemistry and Action of Insecticides. McGraw-Hill, New York, 1951.

Sherman, H.: Comparative profiles of various strains of rats used in long-trem feeding studies. Lab. Anim. Care 13:793$807,1963$.

Shimkin, M.B. and H.H. Anderson: Acute toxicities of rotenone and mixed pyrethrins in mammals. Proc. Soc. Exptl. Biol. mad. $34: 135-138,1936$.

Soyka, L.F.: Determinants of aminopyrine demethylase activity. Biochem. Pharmacol. 18:102.9-1038, 1969.

Sperry, W.M. and F.C. Brand: The determination of total lipides in blood serum. J. Biol. Chem. 213:69-76, 1955.

Starr, D.F., P. Ferguson and T.N. Salmon: Toxicity of allethrin to rats. Soap Sanit. Chemicals 26:108-109, 1950a.

Starr, D.F., P. Ferguson and T.N. Salmon: Toxicity of a synthetic pyrethrin. Soap Sanit. Chemicals 26:139-143, 1950b.

Welsh, J.H. and H.T. Gordon: The mode of action of certain insecticides on the arthropod nerve axon. J. Cell. Comparative Physiol. 30:147-172, 1947.

Wenzel, D.G. and H. Lal: The relative reliability of the escape reaction and righting reflex sleeping time in the mouse. J. Am. Pharm. Assoc. (Sci ed.) 48:90-91, 1959.

Winteringham, F.P.W., A. Harrison and P.M. Bridges: Absorption and metabolism of $C^{14}$ pyrethroids by the adult housefly, Musca domestica L., in vivo. Biobhem J. 61:359-367, 1955.

Yamamoto, I. and J.E. Casida: D-demethyl pyrethrin II analogs from oxidation of pyrethrin I, allethrin, dimethrin, and phthalthrin by a housefly enzyme system. J. Econ. Entomol. 59: 1542-1543, 1966 .

Yamamoto, I. and J.E. Casida: Synthesis of ${ }^{14}$ C-labeled pyrethrin I, allethrin, phthalthrin, and dimethrin on a submillimole scale. Agr. Biol. Chem. 32:1382-1391, 1968.

Yamamoto, I., E.C. Kimmel and J.E. Casida: Pyrethroid metabolism in houseflies: specificity for oxidation of transmethyl group of isobutenyl moiety. J. Agr. Food Chem. $17: 1227-1236,1969$. 
Zeid, M.M.I., P.A. Dahm, R.E. Heim and R.H. McFarland: Tissue distribution, excretion of $\mathrm{C}^{14} \mathrm{D}_{2}$ and degradation of radioactive pyrethrins administered to the American cockroach. J. Econ. Entomol. 46:324-336, 1953.

Zumoff, B. and M.R. Pachter: Studies of rat kidney and liver growth using nuclear counts. Am. J. Anat. 114:479-493, 1964 . 